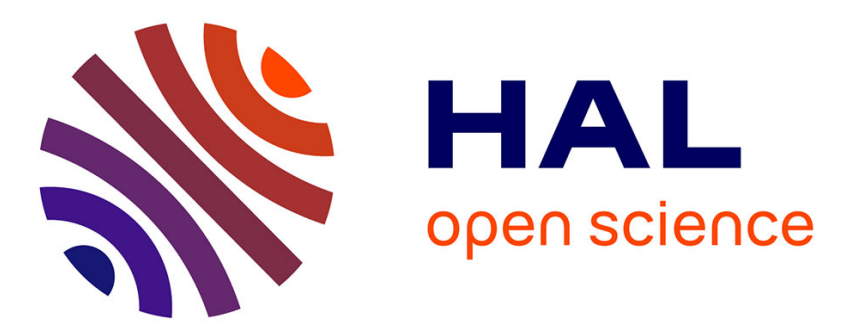

\title{
Advances in identifying GM plants: current frame of the detection of transgenic GMOs
}

\author{
Yves Bertheau
}

\section{To cite this version:}

Yves Bertheau. Advances in identifying GM plants: current frame of the detection of transgenic GMOs. Louise Manning. Developing smart-agrifood supply chains: using technology to improve safety and quality, Burleigh Dodds Science Publishing, pp.43-85, 2022, 9781786767493. 10.19103/AS.2021.0097.04 . hal-03318882

\section{HAL Id: hal-03318882 \\ https://hal.inrae.fr/hal-03318882}

Submitted on 11 Aug 2021

HAL is a multi-disciplinary open access archive for the deposit and dissemination of scientific research documents, whether they are published or not. The documents may come from teaching and research institutions in France or abroad, or from public or private research centers.
L'archive ouverte pluridisciplinaire HAL, est destinée au dépôt et à la diffusion de documents scientifiques de niveau recherche, publiés ou non, émanant des établissements d'enseignement et de recherche français ou étrangers, des laboratoires publics ou privés. 


\section{Advances in identifying GM plants: current frame of the detection of transgenic GMOs}

Yves Bertheau, INRA honorary Directeur de recherche, honorary scientist at Centre d'Ecologie et des Sciences de la Conservation (CESCO), Muséum national d'Histoire naturelle, Centre National de la Recherche Scientifique, Sorbonne Université, France

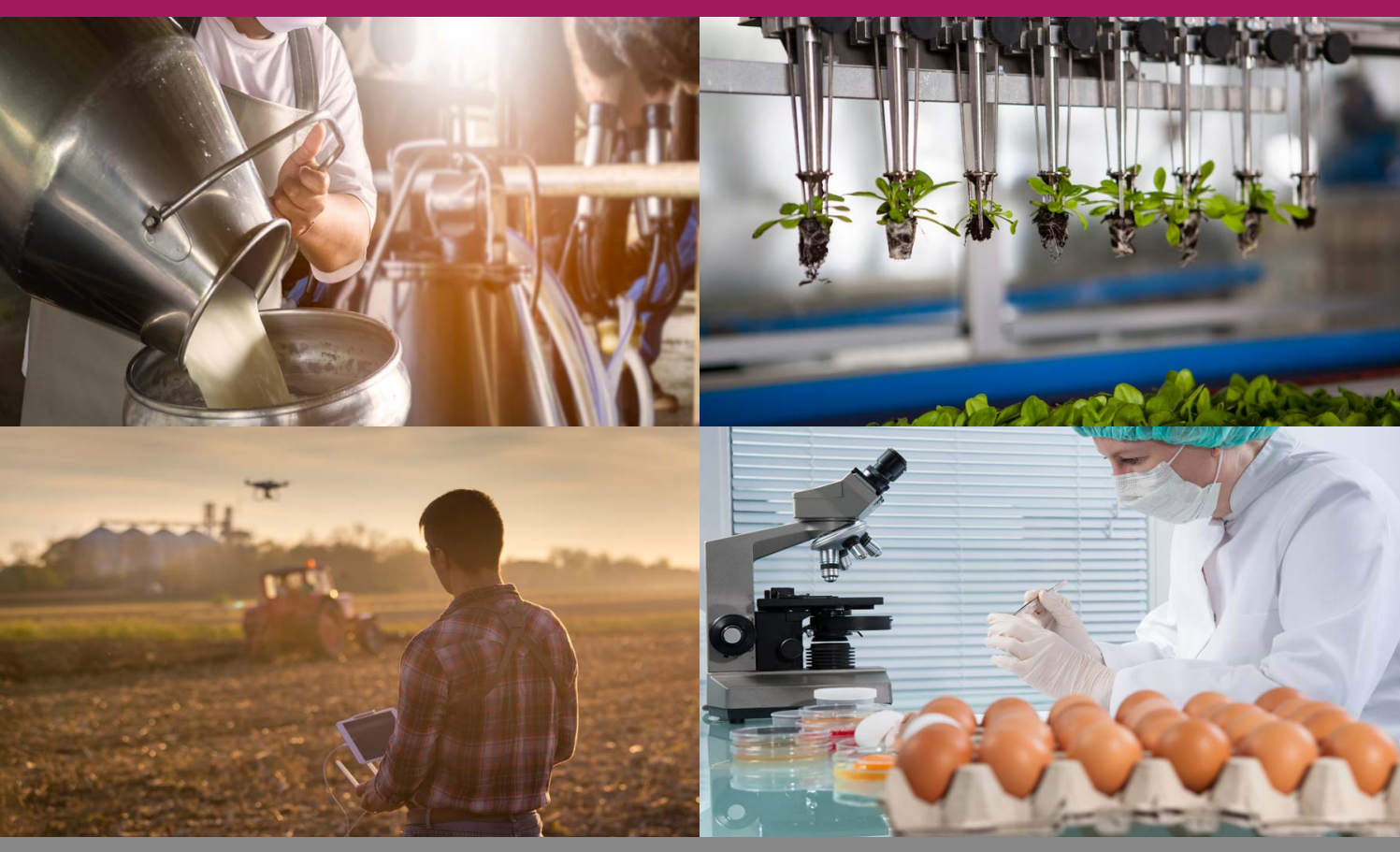




\section{Advances in identifying GM plants: current frame of the detection of transgenic GMOs}

Yves Bertheau, INRA honorary Directeur de recherche, honorary scientist at Centre d'Ecologie et des Sciences de la Conservation (CESCO), Muséum national d'Histoire naturelle, Centre National de la Recherche Scientifique, Sorbonne Université, France

1 Summary

2 The technical framework of the traceability of GMOs

3 Sampling and supply chains coexistence issues

4 Conclusion

5 Where to look for further information

6 References

\section{Summary}

The discovery in the 1980s of the pathogenic mechanisms of Agrobacterium tumefaciens led to transgenesis, a technique for increasing the diversity of traits that could be used in plant breeding. Various other means of plant transformation were then implemented. This new technique was introduced when in vitro mutagenesis was stalled due to the lack of screening systems for mutations, until the description in 2000 of the Targeting Induced Local Lesions in Genomes (TILLING) technique, which was then followed by various developments in plant breeding.

Consumer acceptance of the genetically modified organism (GMO) products resulting from these artefactual transformations differed between countries. In the European countries, with a long culinary tradition and numerous products under official quality labels, the precautionary principle, which had previously prevailed in third countries, was introduced in the face of these new techniques, which at the time had lacked any long history of safe use. From then on, these GMOs were only produced and marketed after a risk assessment. In addition, labelling and traceability, according to the farm-to-fork approach, are required with specific and general post-market environmental monitoring. This chapter describes the scientific, technical and regulatory framework of 
this European traceability system, which allows all European consumers to make informed choices about their food. Moreover, this traceability approach enables the coexistence of genetically modified (GM), non-GM and GM-free supply chains and should thus make it possible to avoid mixing food products with those for pharmaceutical, functional food or industrial use (GAO, 2016b).

The framework we describe in this chapter must be used to deal with the traceability of 'new' GMOs and 'hidden' GMOs. GMOs resulting from the in vitro mutagenesis of isolated cells and new breeding techniques (NBT), so named by the non-governmental organisations (NGOs) and the farmers' union that brought the dispute before the French Conseil d'État (FCE) in 2015, engendered a conflict that led to the European Court of Justice (ECJ) recalling the 2001/18 directive's definition of GMOs in 2018. The feasibility of this traceability of the 'hidden' and 'new' GMOs is discussed in the next chapter.

\subsection{Introduction}

Unlike the many targets considered for the detection or identification of molecules (e.g. aflatoxin) or pathogens, GMOs are a highly political-technicalscientific issue. Thus, when they are discussed or explored in contemporary literature and media, the state-of-the-art techniques and scientific knowledge involved are only partially taken into account (Bertheau, 2019; Davison and Bertheau, 2007, 2009). Despite the passage of 30 years, the definition of GMO is still imprecise and contested. Since 2007, the European Commission, when asked for a legal opinion on the GMO or non-GMO status of NBT products as defined by the Dutch Commission on Genetic Modification (COGEM), was unable to explain them - even during and after the decision in 2018 by the ECJ (European Court of Justice, 2018; Schaart and Visser, 2009). While the US had shown a robust precautionary mindset until the Reagan presidency, the European Union (EU), which was lagging in this domain, began to apply the precautionary principle only after the 1987 conference on protecting the North Sea (Wiener and Rogers, 2002). This consideration of a superior principle (the precautionary principle) soon became apparent in European legislative texts, for instance, about GMOs.

Directive 1990/220, replaced by Directive 2001/18 and then consolidated in Directive 2018/350 (Breyer et al., 2009), was the first legislation regulating the release of GMOs in Europe. It defined a GMO as 'an organism in which the genetic material has been altered in a way that does not occur naturally by mating and/or natural recombination'. This directive was supplemented by Regulation 1829/2003, which regulates GMOs intended for non-crop feed and food, according to the principle of 'one key, one lock' - a way to facilitate authorisations for imported GMOs. Mandatory traceability was implemented by Regulation 1830/2003. As has often been pointed out by various authors, these 
regulations are based on techniques implemented as part of the precautionary principle governing risk assessments. These regulations are in contrast to the approach of third countries that consider only the trait and the presumed related inherent risks. These considerations within European regulations are in line with the European 'White Paper' on health security (European Commission, 2001; Garcia, 2006; Spranger, 2015) and the Cartagena Protocol, where the EU and its Member States (MS) are signatories.

Some terms in the Directive 2001/18/EC, such as 'traditional crossing techniques', are confusing and cause significant technical and legal digression. The minima definition, adopted by the European Commission (Commission of the European Communities, 1992), specifies that: "Traditional breeding" means practices which use one or more of a number of methods (e.g. physical and/or chemical means, control of physiological processes), which can lead to successful crosses between plants of the same botanical family'. This definition, therefore, lays the foundation for the interpretation of 'traditional breeding' in the context of GMOs, which is in line with the recent decisions of the ECJ (July 2018) and of the French Conseil d'État (Conseil d'État, 2020). Another ambiguity surrounds the generic term 'genetics'. The rational interpretation would be that, given the progress of scientific knowledge over the past 30 years, this term also includes epigenetics and epitranscriptomics. However, up to now, interpretation based on sound science has had no significant repercussions in the European risk assessment guidelines and procedures.

Epigenetics (DNA methylation and 'histone code') and epitranscriptomics (RNA modifications), among others such as organelles' genomes, are indeed not taken into account in the current European Food Safety Authority (EFSA) risk assessments. In contrast, the transmission of those changes to offspring - a significant risk assessment element in biology and a crucial point in European directives - has long been proven. A recent EFSA colloquium on epigenetics, a term defined in 1942 by Conrad Waddington, recorded that little knowledge was available (EFSA et al., 2016). Epigenetics is the study of how genes and their products influence the expression of the phenotype in a given organism, free from any activity that involves genetic alteration. This definition evolved to describe epigenetics as being 'primarily concerned with the mechanisms through which cells become committed to a particular form or function and through which that functional or structural state is then transmitted in cell lineages' (Jablonka and Lamb, 2002, p82). The lack of consideration of these transmission mechanisms to descendants is clearly in contradiction with the European precautionary principle. Therefore, the European directives 1990/220, 2001/18, and 2018/350 do not address the transmissibility of artefactual genetic, epigenetic and epitranscriptomic and organelles' modifications arising from techniques which are still currently under development. The regulatory situation in other countries for GMOs and 'new 
GMOs', whether or not they are signatories to the Cartagena Protocol that we discuss here, seems even more complicated (Friedrichs et al., 2019a,b; GAO, 2016b; Van Eenennaam et al., 2019).

\subsubsection{The Cartagena Protocol on Biosafety}

This 2000 International Protocol (CPB), which came into force in 2003, was implemented in the EU by Regulation 1946/2003. It uses a GMO definition slightly different from the European one but covers all in vitro mutagenetic (production of genetic mutations on isolated plant cells) techniques. The protocol is restricted to the living modified organism (LMO), i.e. its capacity for dissemination and reproduction and therefore, fundamentally, that which could impact ecosystems. Thus, the Europeans, signatories to the protocol, accepted this LMO concept where the definition corresponded well to the European directives (Husby, 2007).

From 2010, the 'Nagoya-Kuala Lumpur Additional Protocol' implements Article 27 of the CPB. Under this treaty, supply chain operators (stakeholders placing products on the market, producers, exporters, importers and transporters) will be held responsible, including financially, for the movement of LMOs between the MS and any potential damage caused. The EU, a signatory to this protocol ratified by the MS, must therefore be able to identify the LMOs produced or in transit through its territory and must inform the importing third countries (1946/2003,65/2004). European companies are thus responsible if there is an insufficient qualification of their living products in this respect, such as seeds.

\subsubsection{The 'proven safety' of GMOs}

Directives 2001/18 and 2018/350 specify: 'This Directive should not apply to organisms obtained through certain techniques of genetic modification which have conventionally been used in a number of applications and have a long safety record'. The appreciation of a long history of proven safety can only be judged on the history of the techniques used and their mass production. The 2018/350 Directive offers an explicit reference to what cannot be considered 'a technique traditionally used for various applications and whose safety has long been proven'. Transgenesis is included in its Annex 1A, among the new techniques producing GMOs, offering a valuable indication of the legislator's intention when deciding not to consider the process as traditional and of proven safety. Therefore, the timeframe for transgenic plants were 1983 for the proof of concept, 1986 for the first field experiments, 1990 for the first commercial genetically modified (GM) tobacco, 1994 for the first commercial GM vegetable, tomato, and 1996 for the first mass-marketed soybean. Thus 
2001, the year of the Directive's release, can be considered the beginning of the safety monitoring of GMOs.

Conversely, what were the techniques developed during the previous decades from 2001 that could have resulted in commercial products that would be of proven safety, a fortiori in 2020 ? The participants of an international symposium in London in 2016 concluded that the set of in vitro techniques, that is, the use of isolated plant cells, used in transgenesis and genome editing techniques, had changed very little over these decades (Altpeter et al., 2016; Hiei et al., 2014; Ikeuchi et al., 2019; Ledford, 2016; Maher et al., 2020; Que et al., 2014).

Apart from the first transgenic GMOs within the meaning of Directive $2001 / 18$ and the in vivo mutagenesis identified by the Food and Agriculture Organization (FAO), no variety derived from in vitro cultures of isolated cells was listed before the 2000s (National Academies of Sciences Engineering and Medicine, 2004; National Research Council, 2009). Therefore, the in vitro cultures of isolated cells had no proven safety record.

Finally, the genotype-phenotype relationship of mutations transmissible to offspring remains an overall unmet challenge. Despite the progress in sequencing, the somaclonal variation, random mutations and epimutations remain challenging to exploit, except for rare traits that are easily selectable, such as pesticide tolerances. It was only at the beginning of the twenty-first century that the TILLING technique enabled their exploitation through costly 'high-throughput' platforms, capable of screening thousands of mutants and making it possible to exploit, by marker-assisted selection, some of these random mutations and epimutations (Anderson et al., 2016; Irshad et al., 2020; Manzanares et al., 2016; McCallum et al., 2000a; McCallum et al., 2000b; Unterseer et al., 2014). The difficulties in the adaptation of TILLING to various species and the costly installation of platforms that were able to screen the numerous mutants, which took several years, meant a delay in delivering practical outcomes despite some recent 'speed breeding' (Kurowska et al., 2011; Pratap et al., 2018, Watson et al. 2018).

Indeed, with the current state of the available scientific and legal data and the absence of traceability and post-marketing surveillance systems, it is estimated that the minimum necessary duration to enable confidence in the demonstration of a long-proven safety could be well above 30 years.

\subsection{3 'Hidden GMOs' and new techniques for modifying genomes and epigenomes}

We have previously mentioned the ECJ and the FCE decisions. This challenge is currently decisive in the political definition of GMOs that should be traced. In 2007, the Dutch COGEM had drawn up a heterogeneous list of various techniques (the NBTs) for which the European Commission was questioned as to the GMO 
status, or not, of the resulting products (Schaart and Visser, 2009). The lack of a legal response from the Commission allowed the various stakeholders to ensure that the resultant products were not GMOs as envisaged by some third countries.

This absence of a response from the EC proved to be a loophole into which companies rushed. The marketing of varieties which were tolerant to herbicides ( $\mathrm{VrTH}$ in French), with unknown status and for which the breeding processes were not available at the time of registration in the national catalogues of cultivars, was the catalyst to close this loophole. In 2015, in response to the herbicide-tolerant varieties, such as Clearfield rapeseed, a consortium of nine French environmental associations and agricultural unions filed an action before the FCE to annul an article of the Environmental Code which excluded organisms obtained by 'mutagenesis' from the scope of French GMO regulations. In 2016, the FCE considered it necessary to seek the opinion of the ECJ on four questions of interpretation of the European law, while adding requests on the status of products resulting from new techniques for modifying genomes and epigenomes. In 2018, the ECJ reminded ${ }^{1}$ that organisms obtained by mutagenesis (thus including in vitro, i.e. with a step of isolated cell cultures) are indeed GMOs within the meaning of Directive 2001/18, with a few ones being exempted. The Annex I.B.'s exemption applies only to mutagenic techniques developed mainly before its adoption and whose products would have demonstrated a proven safety (implied by prolonged commercial use).

This ECJ decision conformed with the definition of traditional breeding found in Directive 90/220 and the above recalled 1992 CEC's definition. Therefore, the GMO Directive was determined to cover organisms derived from in vitro cultures of isolated cells and NBTs (as new techniques mainly developed after 2001). As a result, the Conseil d'État enjoined the French government in February 2020 to (i) amend the Environmental Code and to (ii) establish a restrictive list of mutagenesis techniques or methods traditionally used for safety purposes that have long been proven, allowing their exemption. The French Government was finally asked to identify, within the Official Catalogue of Varieties, varieties obtained by mutagenesis techniques that were mainly developed after the adoption of Directive 2001/18. Those cultivars should have been subject to the obligations applicable to GMOs, in terms of risk assessment, prior authorisation and traceability and labelling in particular (GAIN USDA, 2021), and, thus, should be withdrawn from the market. The draft decree of the French authorities triggered a community barrage of questions and concerns.

In November 2019, The Council of the EU requested ${ }^{2}$ the Commission (Council Decision (EU) 2019/1904) to submit, by 30 April 2021, 'a study in light of the Court of Justice's judgment in Case C-528/16 regarding the

1 https://eur-lex.europa.eu/legal-content/FR/TXT/?uri=CELEX:62016CJ0528

2 https://ec.europa.eu/food/plant/gmo/modern_biotech/new-genomic-techniques_en 
status of novel genomic techniques ${ }^{3}$ under Union law' (Directives 2001/18/ EC and 2018/350, Regulations (EC) 1829/2003, Regulation (EC) 1830/2003 and Directive 2009/41/EC). This EC request for April 2021 did not prevent the Commission from delivering in advance its conclusion to the French authorities in 2020 about the project of the French decree. An anticipated reply that still militates in favour of political decisions of principle instead of legal and scientific considerations.

The decision of the ECJ is binding and cannot be appealed against. Therefore, in Europe, GMOs' traceability must target any organism that has gone through a phase of isolated cells in in vitro culture, including those obtained by adding new techniques.

\subsubsection{The mutagenesis exemption}

The $2001 / 18$ and $2018 / 350$ directives are based on the precautionary principle, by defining GMOs as human-mutated-artefactual-organisms. They are exempt from the requirements of risk assessment and labelling for the products of techniques with numerous applications and a long safety record at the 2001/18 adoption time. As previously stated, they were no clear indications about which products were to be considered, but the techniques' history made itclear. Several stakeholders, MS and EC executives took the in vivo mutagenesis techniques started in the 1930s as an example of exempted methods. For these actors, the in vivo International Atomic Energy Association (IAEA) mutants rather massively developed since the 1950s are adequate proof of any random mutagenesis in the requested long history of safety. The stakeholders and executives had then argued that in vitro mutagenesis was an in-depth technique developed before 2001 in continuity with the in vivo IAEA-listed mutants. Thus, according to them, in vitro mutagenesis should be considered as the continuity of the in vivo one, and in vitro-derived mutants should thus be exempted. However, as pointed out by Thorpe (2012):

'During the 1990s, continued expansion in the application of in vitro technologies to an increasing number of plant species was observed. However, only limited success has been achieved in exploiting somaclonal variation (Karp, 1994) or in the regeneration of useful plantlets from mutant cells (Dix, 1994); also, the early promise of protoplast technology remains largely unfulfilled (Feher \& Dudits, 1994)'.

There would thus be an apparent drastic technical and historical discontinuity between in vivo and in vitro techniques. The reasoning is also supported by the effective use of in vitro mutants only after the publication of the TILLING technique in 2000 (McCallum et al., 2000a; McCallum et al., 2000b). Indeed, the 
induction of DNA-damaging mechanisms might differ between the in vivo and in vitro techniques (Brash and Hart, 1978; Krishna et al., 1987). A certain stochasticity of 'rebel' cells will impede a direct complete 3D regeneration from a totipotent isolated cell. A totipotent cell is a single cell that can give rise to a new organism. Thus, several external impulses are necessary to induce the development of organisms (Mojtahedi et al., 2016; Richard et al., 2016). Drug discovery and cancer studies are some of the areas of advanced biology which require the 3D organisation of cells, for example, by creating organoids (3D tissue cultures) when the whole organism is not suitable. Indeed, the varying cell types, spatiotemporal organisation, diffusion gradients and the molecular contents in the interior and the immediate environment; that is, the interactions between the cells and matrix(s), in an organoid, are more representative of life than isolated cell cultures (Edmondson et al., 2014). Epimutations can be observed after in vitro fecundation (fertilisation) but not in in vivo-conceived children (Peters et al., 2015; Song et al., 2015). Similarly, the somaclonal variations caused in plant cell cultures vary according to the species' reproductive biology, the cultivar and the number of individuals used, and the culture protocol, which does not promise any in vivo-in vitro continuity (Martínez, 2018; Skirvin et al., 1994).

The cells and tissues sense their environment and communicate to coordinate themselves through diverse molecules, including nucleic acids whose natural epigenomic 'decoration' (patterns) is essential for non-selfidentification (Hammarlund et al., 2020; Monticolo et al., 2020; Sablowski, 2016). This essential epigenetic profile is generally lost during in vitro manipulations. Exocytosis is an in vivo phenomenon of how the cell transports molecules so that they can be released from the cell without a corresponding model in vitro, while polyploid plants exhibit more significant variability in plants regenerated in vitro (Gavazzi et al., 1987; Ruiz et al., 2020; Skirvin et al., 1994; van den Bulk et al., 1990; Žárský et al., 2009). Multicellular organisms evolve by selecting, in vivo, the germinal and meristematic cells 'resistant' to mutations and epimutations, the opposite of in vitro somaclonal variation (Balestrazzi et al., 2020; Burian et al., 2016; Morrow, 1975). This idea of in vivo selected cells protected from the effect of mutagens is found in other somatic mutation studies (Franco et al., 2019). Indeed, some species seem to have evolved by selecting low rates of somatic mutations and epimutations, which do not correspond to the variations observed in vitro (Hofmeister et al., 2020; Orr et al., 2020). Thus, the in vivo and in vitro stages and mutageneses look dramatically different, and these legal and biological traits interact with GMO traceability issues.

\subsubsection{Summary}

The remainder of this chapter, and the next one, will consider the various techniques used to generate GMOs within the ECJ and FCE context. After a 
section dedicated to the current European frame in place for GMO traceability, this chapter will also explain the elements that are considered to be scars and signatures which could likely detect and identify new GMOs, and even suggest the technique used at their origin. 'Scars' are the unintended genetic and epigenetic modifications due to techniques related to isolated cells in in vitro cultures. 'Signatures' are both the unintended changes and the molecular patterns necessary for a mutagenesis technique to be performed, such as gene editing.

Due to the EC and MS' inability to launch research programmes on detecting and identifying 'hidden'4 and new GM varieties and prove their artefactual character, since February 2020, many stakeholders and some policymakers and scientists have expressed that the ECJ's decision cannot be implemented (Haut Conseil des Biotechnologies (HCB), 2017; Scientific Advice Mechanism (SAM), 2017; Vain, 2007; van der Meer et al., 2021). Indeed, compared to transgenic GMOs with the random insertion of foreign DNA providing a univocal molecular signature, the new challenge is that with the similarity of the essential components of organisms such as nucleotides and DNA, cut repair systems are impeding us from distinguishing, easily in one step, some targeted modifications that may be natural or artefactual, such as SNV and indels of SDN1 ${ }^{5}$ and SDN2 (Rostoks, 2021). This is a way of saying that a sand dune and a skyscraper are indistinguishable because they are both made from sand.

However, the European Network of GMO Laboratories (ENGL) recognised that analytical traceability was possible to facilitate the enforcement of procedures, if enabled by the classification of products as GMOs (European Network of GMO Laboratories (ENGL), 2019). The information gathered from notifiers could allow laboratories to develop identification methods by considering several converging elements, such as molecular markers, in a matrix approach. These elements, that would make these products from NBT in vitro cultures detectable and identifiable, and the applicable European GMO regulations, differentiating them from spontaneously mutated products, are now considered. The transgenesis-derived GMOs can serve as a framework and model for the detection of these 'new GMOs'. The lack of engagement, ${ }^{6}$ created by the European Commission's refusal in $2017^{7}$ to let ENGL work on the detectability of products derived from NBTs, should not be repeated. Indeed, all techniques and targets exist for the classical detection of these new GMOs. The detection techniques required have been developed in recent years by the ENGL network of laboratories (Holst-Jensen et al., 2012, 2013).

4 The French $\mathrm{VrTH}$ (herbicide-tolerant varieties such as Clearfield rapeseed)

5 Sequence-Directed Nuclease Mutagenesis

6 https://www.infogm.org/6646-ue-experts-se-penchent-methodes-de-detection

7 https://www.infogm.org/6678-nouveaux-ogm-commission-europe-veut-elle-tracabilite https://www.infogm.org/66 79-new-gmos-does-european-commission-want-them-traceable 


\section{The technical framework of the traceability of GMOs}

\subsection{Introduction}

Preliminary studies with stakeholders have made it possible to define a threshold for exemption from GMO labelling in a situation of adventitious (accidental) or technically unavoidable presence (Bertheau, 2002; Bertheau et al., 2002; Davison and Bertheau, 2007; Regulations 258/1997 then $2015 / 2283,49 / 2000,50 / 2000,1830 / 2003)$. The unit was not defined in these scenarios, but the reasoning and data were based on polymerase chain reaction (PCR)-targeted DNA techniques, which were later formally endorsed by the ENGL network. The European General Food Law (Regulations 178/2002, 2019/1381) made traceability a mandatory 'one step forward and one step back' for all food products, including GMOs. It established the EFSA and the European Union Reference Laboratories (CRL-GMFF renamed EURL-GMFF), installed for the first time in a European authority (JRC, Ispra, Italy). Regulation 1830/2003 established an administrative traceability system for easily placing genetically modified (GM) food/feed on the EU market. It further complemented Article 21 of Directive 2001/18/EC by exempting labelling products below a $0.9 \%$ threshold of adventitious (accidental) and technically unavoidable presence of GMOs. A European network of State Control laboratories and research laboratories was informally set up in Ispra (Italy) in 1999, based on the Belgian and French network models. This network was officially opened by the European Commissioner for Research, Philippe Busquin, in December 2002. This ENGL network for GMO detection has since integrated the National Reference Laboratories (NRL), established by Regulation 1981/2006.

The various regulations and directives oblige the GMO producers who wish to market their products in Europe to provide a detection/identification/ quantification method and the control material for interlaboratory validation of the procedure provided. In addition, a commercial source of reference material must be made available to private and enforcement laboratories. Originally prepared from seeds certified at the JRC IRMM ${ }^{8}$ of the European Commission, the production of these reference materials, at this time, originated from seeds as powder and then in DNA form, but was gradually transferred by the petitioning companies to a private actor. The quality of this new reference material was recently judged to be flawed by the enforcement laboratories. The ENGL and the NRL had to re-specify the rules and criteria ${ }^{9}$ of production in the face of these producers' laxity (EURL-GMFF, 2019b). 
Most of the ENGL research laboratories participated in the FP4-FP7 10 European programmes. Those projects focused on GMO traceability strategies (QPCRGMOFood and GMOChips), on cultures' co-existence (SIGMEA) and finally the traceability and co-existence in the whole supply chains (Co-Extra, the largest of those European research programmes) (Bertheau, 2013a; European Commission, 2010).

As in other areas of food safety, these control laboratories are seeking ISO 17025 accreditation. Therefore, the laboratories participate in private, national and EURL-GMFF ${ }^{11}$ proficiency tests (Broothaerts et al., 2020; International Standard Organisation (ISO), 2017; Ribarits et al., 2021; Trapmann et al., 2014; Žel et al., 2006). The ENGL laboratories also participate in the interlaboratory validations of the petitioners' methods. Therefore, the ENGL laboratory network is the technical, regulatory and scientific backbone of a complex detection domain whose goals, functionalities and rules are still evolving. The European Commission strongly supervises/verifies that there should be this world reference in GMO traceability.

Before any scientific consideration, the definition and controls of GMOs depend fundamentally on political negotiations as much as its measurement unit, and this frames the technical, scientific and the recent legal upheavals.

\subsection{Traceability in the GMO context}

Traceability is a vital requirement for consumers, European consumers in particular. Traceability is the ability to trace the history, application, use and location of an item or its characteristics through recorded identification data. As stated by the Codex Alimentarius, 'Traceability is the ability to track the movements of a food among the specific stages of production, processing and distribution', a statement following the EU's 'Hygiene Package' (Dwinger et al., 2007). Document-based traceability is the first requirement along foodprocessing chains. It is a prerequisite for compliance with the international specific quality management standards (ISO 9000:2015, ISO 9001:2015) and is linked with food safety standards (ISO 22000:2018 and ISO 22005:2007). Traceability is mandatory in the EU since the General Food Law (178/2002 regulation) of the 'Hygiene Package'. The information must be available 'one step forward and one step back', and traceability documents must be retained for GMOs for a minimum of five years. This regulation avoids any distortion of competition and additional costs in the EU. Indeed, the GMOs' documentary traceability requirements do not differ from the other EU-mandatory traceability obligations. This device was implemented to satisfy the precautionary principle 
introduced by the community 'White Paper' of 2001 (Aerni, 2019). The complete integration of the general procedures for traceability and alerts in the EU has enabled the development of a reliable traceability system for GMOs, included in the RASFF ${ }^{12}$ alert system, without additional cost (Demortain, 2011; Parisi et al., 2016; Price and Cotter, 2014). However, despite these regulatory controls, fraud, adulteration and accidental contamination, whether or not due to human error, are still possible, although control systems such as the blockchain, may reduce the products' falsifiability (Demestichas et al., 2020).

The history of GMOs is indeed a long process of unexpected contamination of seeds and food chains, due to human errors in particular, for example, by unauthorised products such as StarLink ${ }^{\circledR}$ (intended for the industry) or Prodigene (intended for pig vaccination) corn varieties (Ellstrand, 2003; Price and Cotter, 2014). This inability to trace GMOs in some areas of the world was exacerbated after September 2001 when the US authorities' concern increased about their failure to protect themselves from malicious GMOs, especially if they were possible weapons of bioterrorism/biowarfare. The US Government Accountability Office (GAO) recommended strengthening the cooperation between the US agencies concerning traceability, which could have led to a convergence of operations between the regions of the world (Davison and Bertheau, 2008; GAO, 2008, 2016a, b). The fight against bioterrorism spurred the development of PCR devices or other detection systems, miniaturised and usable in the field or storage silos, together with techniques and strategies applicable for the detection of unknown biological elements and unknown GMOs such as NBT products (Hedman et al., 2018; Holst-Jensen et al., 2011; Minogue et al., 2019; Parida et al., 2020; Sugumar and Kong, 2008).

Transgenic GMOs provide unambiguous signatures by their random insertions and sometimes rearrangements of the insert, but the need to control analytical costs led to the development of the 'matrix approach'. The primary goal of this approach was to determine the elements common to several GMOs to establish screening strategies, followed by the identification-quantification for authorised GMOs. Thus, the databases made it possible to identify the most authorised GMOs' unequivocal profiles (patterns). Any discrepancy with these profiles allowed a suspicion of the presence of unauthorised $\mathrm{GMO}(\mathrm{s})$. Any information (sequence, geographical origin, nature of the processed product or whistle-blower alerts) can also be used. This matrix approach was adopted in all control laboratories. Such multi-parametric multi-step methods are used in many detection/identification fields with workflow systems, such as metabarcoding (Liu et al., 2020a) or other decision-making tools (Ruttink et al., 2010; Bellocchi et al., 2010; Bohanec et al., 2013). The detection of unknown GMOs is also possible, through a variant of the matrix approach 


\section{Current transgenic GMO detection scheme}

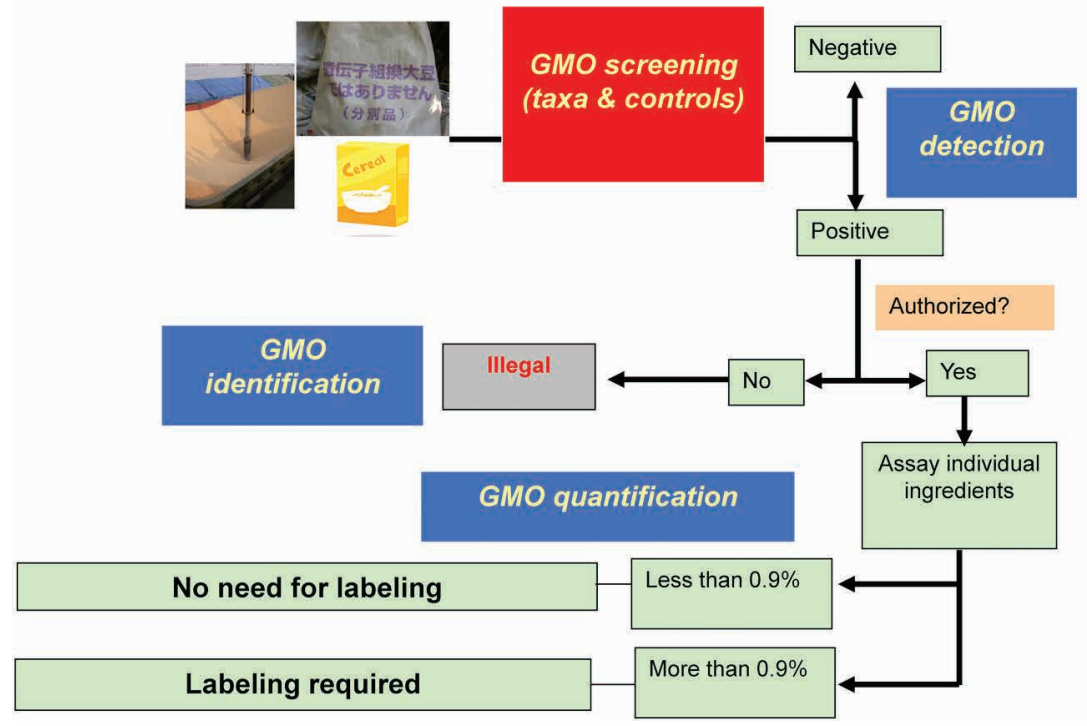

Figure 1 Current two-step procedure for the detection of transgenic GMOs. The matrix approach can be implemented more in depth, when necessary, e.g. for unknown GMOs.

- the differential quantitative PCR - which works by quantifying the sequences common or not to several GMOs (Cankar et al., 2008; Gruden et al., 2013). Detecting and univocally identifying one or more GMOs, even the unknown ones, with the matrix approach, is more straightforward than identifying the taxa of an ecosystem (Ruppert et al., 2019).

Due to the strong consumer rejection of these new products, the detection of GMOs from transgenesis developed rapidly (Regulation 258/1997 then 2015/2283) (Levidow and Marris, 2001; Gaskell et al., 2004; Kantar, 2019). The multiplication of GMOs was accompanied by a census of their characteristics in tables, and then in databases such as GMOMETHODS ${ }^{13}$, GMDD $^{14}$ and EUGenius $^{15}$ (Hemmer, 1997; Dong et al., 2008; Bonfini et al., 2016). These databases made it possible to organise the cost-effective analyses by successive steps, to determine one or several GMOs - from the screening step, using elements common to several GMOs, to a unique GMO identification, through its patterns or its unequivocal signature, followed by quantification. Various private or public tools were subsequently developed on the web, ${ }^{16}$ or 
as the JRC pre-hybridised and implementable probe plates (Angers-Loustau et al., 2014). This type of methodological approach (see Fig. 1) provides a standardised basis (CEN/TS 16707, 2014) that can be extended to other targets, as discussed later in this and the next chapter. Varieties, like the Elite varieties of commercial cultivars, pangenomes and structural variants are also identifiable by such approaches (Alonge et al., 2020; Li et al., 2018; Sohn et al., 2017), for example, by detecting lesions in non-replicating DNA (Moreno et al., 2016). This polymorphic, multi-target screening step is capable of targeting from point variant to chromosomal rearrangement. It uses simplex or multiplex PCRs in e.g. SNPLex or DNA chips (Hougs et al., 2017; Wilkesa et al., 2016). Figure 1 presents a very simplified scheme of data analysis for identifying the GMOs of an agri-food product. Some determination criteria - such as epigenetic and epitranscriptomic modifications - have not been incorporated, for ease of reading. However, the principle remains the same: after organising the data, the analyses by dichotomous choices classically used in the detection of transgenic GMOs will allow, with the help of decision support tools (tables, decision support systems (DSS), artificial intelligence) to detect any new GMO, such as NBT products, and to verify that the traits used in the detection and quantification are not natural because they are integrated into an artefactual context, the unequivocal signature of the GMOs. The convergent flow of evidence, given as an example in Fig. 1 of the next chapter, is particularly illustrated in the case of an SDN1 or SDN2 modification; an SDN3 change would be identified by the univocal signature of the insert's edge fragments (these modifications are discussed further in the next chapter).

The analytical methods in this context must meet several objectives at the lowest cost, to identify and quantify a target and allow a multi-target approach to detect unknown GMOs. Various alternative methods have been developed, such as the bioassay of plantlets (e.g. herbicide-tolerant soybean seedlings) or infrared detection, to avoid the destruction of valuable material or large quantities of material (Anklam et al., 2002; Burgos, 2015). This last method might lead to a suspicion of the presence of unknown GMOs (Bonfini et al., 2001; Michelini et al., 2008; Fumiere et al., 2009). These methods have not experienced any commercial or enforcement developments.

Some immunological methods continue to demonstrate that they are of interest in some specific situations. An immediate benefit of the development of GMO detection methods in the early 2000s was the standardised development of methods and procedures used later on in other detection sectors; however, the associated societal benefit, positive externalities and an essential return on investment are difficult to quantify (Davison and Bertheau, 2007, 2009; Bertheau and Davison, 2013). 


\subsection{The DNA target molecule in detection}

DNAwas chosen as the preferred targetfor this approach to analytical traceability, as the methodology is usable (i) from the field to the final consumer, with (ii) a continuity of detection available along the supply chains, and (iii) the versatility of the approaches it provides from the screening of sequences common to several GMOs to the quantification of univocal sequences, and (iv) agility from the sequencing of short, amplified fragments to e.g. the chromosome walking for the identification of unknown GMOs. DNA preserves well. It can be found in ancient, mummified and fossilised samples and products after many industrial processes, even if the size of the extractable fragments has decreased. The decrease in size is not too much of a problem, since quantification in quantitative real-time PCR (QRT-PCR) and other derived techniques are more reliable with relatively small pieces. Only highly refined products, such as certain industrial sugars and oils, contain such small amounts of DNA that the analytical cost becomes prohibitive.

The DNA unit proposed by the ENGL network was accepted by the European Commission (2004/787). The method for calculating the GMO content (GMO\%) is based on the haploid genome unit:

$$
\text { GMO\% }=\frac{\text { Copy Number of the GMO-specific sequence }}{\text { Copy Number of the Taxon }- \text { specific sequence }} \times 100
$$

The PCR, qualitative or quantitative real-time, is the dominant target amplification technique for (i) its sensitivity, (ii) its specificity at several levels (from point mutation to structural mutant) and (iii) its versatility (detection, sequencing, nested-PCR to improve specificity and sensitivity and a combination of techniques such as SNPLex and amplification for hybridisation on DNA chips). However, some limitations in multiplexing, especially the amplification errors, are often forgotten, for example, in preparing sequencing libraries. The development of small amplification devices, driven, for example, by biodefense's needs, allows their use from the seed to the field, from the grain silo to the transformed product through the cargo. Signal amplification techniques have not been successful, particularly following ORT-PCR development with a calibrator (Miao et al., 2015; Vora et al., 2008). Some other target amplification techniques continue to be used or even take precedence over PCR in some situations. Of particular note is the current trend towards isothermal nucleic acid amplification techniques such as LAMP, RPA and NASBA (Bodulev and Sakharov, 2020; Kumar et al., 2018), with less sophisticated and cheaper devices and generally much shorter amplification time. The lower need for extraction and purification of target DNA due to lower sensitivity to inhibitors gives these techniques another advantage. 
Moreover, they can be easily used for DNA and RNA amplification at different points of need, such as fields (Zou et al., 2020), with more understandable readings when coupled with qualitative detection towards a dipstick (Lateral Flow Device) or flocculation (Singh et al., 2019b, Mason and Botella, 2019). On the other hand, the more complex methodological developments, such as the need to define four or six primers or accentuated constraints in multiplexing, without taking into account the effect of various inhibitory reagents, hamper their use, which has not yet been integrated into the standards and methods proposed by the notifiers (Parida et al., 2008; Lobato and O'Sullivan, 2018; Zou et al., 2020). Ligase Chain Reaction (LCR) is a technique able to detect point mutations and is used in multiplex techniques such as SNPLex (Chaouachi et al., 2005). New techniques which do not use enzymes, such as the Host Cell Reactivation (HCR) Assay, and could be used on-site (point-of-need), are not yet in the GMO methodological pipelines (Ikbal et al., 2015; Ouyang and Han, 2019).

The use of digital PCR (ddPCR) is another discernible technological trend. This application of limit dilution sub-sampling techniques has the advantage of reducing the effect of PCR inhibitors (Quan et al., 2018) and their dependence on reference materials of fluctuating quality and availability.

Indeed, some GMOs withdrawn from the market can take years to disappear from supply chains, but remain quantifiable (Regulation 619/2011). This regulation also established a $0.1 \%$ tolerance threshold for unauthorised GMOs in feed to ease the flow of international trade, provided the EFSA had studied the dossier. Such a threshold does not apply to food or seeds.

These simplex or multiplex techniques have been completed by highdetection density techniques such as biosensors, microarrays and DNA chips, for which the amplification of the signal and the target can increase the detection sensitivity (Chen et al., 2018; Vora et al., 2008). These types of multi-target biosensors, previously developed by the European GMOChips programme, are particularly well suited for screening and the matrix approach (Chaouachi et al., 2005; Gruden et al., 2013; Holst-Jensen et al., 2013; von Gotz, 2010). Tiling chips could also be adapted for GMO detection purposes (Gregory et al., 2008).

\subsection{Other GMO detection targets}

Inexpensive and rapid, the immunological tests developed are still used by some operators but have not been integrated into the routine of state controls (Fraiture et al., 2015; International Organization for Standardization (ISO), 2004; Stave, 2002). Some proteins may be present in several GMOs, thus preventing the differentiation between authorised and unauthorised transformation events, while the protein production varies significantly 
between tissues and varieties (Grothaus et al., 2006; SeedQuest, 2011; Van den Bulcke et al., 2007). In some cultivars, the protein content may be even lower than the quantification limit. Nevertheless, the immunological tests have proven their usefulness for operators, particularly in some particular cases such as Cry9C, the only reported case of a protein specific to a transformation event. Indeed, immunological tests were used to remove StarLink ${ }^{\circledR}$, a GM corn approved for industrial use and animal feed, from the food market, which would have cost nearly US\$1 billion ${ }^{17}$ (Bratspies, 2003; Diaz et al., 2002; Price and Cotter, 2014; Schmitz et al., 2005). StarLink ${ }^{\circledR}$ was the first example of a long and controversial series of contaminations due to insufficient supply chain segregation. These tests can be used mainly in the field or at harvest and transport to silos, and are still used in production quality control in the seed field as for RoundUp Ready ${ }^{\circledR}$ soybeans, that is, mainly with self-pollinated species. Nevertheless, these immunological tests (Agdia, SDIX, EnviroLogix, Creative Diagnostics) are still used for dispersion studies (Strain et al., 2014), or as versatile screening means, for example, in 'GMO-free' supply chains (Identity Preservation, Eurofins).

Epigenetic and epitranscriptomic targets have so far not been considered in the case of transgenic GMOs. These targets are nevertheless detectable but do not have the critical feedback from the DNA target detection (Bey et al., 2016; Fojtová and Fajkus, 2020; Mozgová et al., 2015). Apart from the reverse transcription usable for RNA detection with PCR (RT-PCR), nucleic acid sequence-based amplification (NASBA), strand displacement amplification (SDA), recombinase polymerase amplification (RPA) and various other methods will be applicable in GMO traceability (Zhao et al., 2020).

\subsection{DNA extraction}

The matrix effect is often underestimated, as for PCR for sequencing libraries (Pasquali et al., 2019; Robin et al., 2016). From the beginning of GMO detection, it was necessary to choose between a general lysis-extraction process followed by a purification step and specific processes adapted to each matrix. The latter choice would have increased the accreditation efforts and training of personnel to different methods. The current consensus is to use a general technique, most often CTAB-based, followed by purification to reduce the amount of inhibitors present (International Organisation of Standardization (ISO), 2005a). The phenol-chloroform process remains the best on a diagnostic lab scale but can be discarded for its risks (Bonfini et al., 2001; Piskata et al., 2019; Sajali et al., 2018). The dramatic difficulties faced with DNA extraction explain the absence 
of an ISO standard. This difficult extraction step partly explains the growing success of alternative amplification methods to PCR and ddPCR, which are less sensitive to PCR inhibitors (Walker and Hsieh, 2019).

Specific matrices and highly refined products are always subject to peculiar treatments (Corrado, 2016; Demeke and Jenkins, 2010; Gryson et al., 2002; Waiblinger et al., 2007). Documentary traceability, with the conservation of samples before processing, is then essential. Ideally, the sample preparation should allow several analyses, including screening - which is a subset of the matrix approach - followed by identifying the GMOs, all with sufficient replications to assess the measurements' variability (Block et al., 2013; Gerdes et al., 2012a).

\subsection{GMO quantification}

The QRT-PCR assay remains the method of choice for its versatility, especially the standardisation that has accompanied it, despite alternative quantification techniques (Holst-Jensen et al., 2006; International Organization for Standardisation (ISO), 2005c, d, 2006). The availability of reliable reference materials is currently necessary for this technique. The matrix approach and the detection of epigenetic and epitranscriptomic changes also require reference materials that are as complete as possible, such as crushed seeds. Indeed, the current trend to develop alternative certified reference materials, such as plasmids, or suppress them in front of the ddPCR, poses a risk for current and future applications of, for example, the matrix approach or chromosome walking (Trapmann et al., 2010; Caprioara-Buda et al., 2012; Deprez et al., 2016).

Qualitative immunological or PCR methods can be used with subsampling strategies, of which ddPCR is only an application, to determine the GMO content according to a previously defined threshold (Bertheau and Kobilinsky, 2004; Kobilinsky and Bertheau, 2005; International Organization for Standardization (ISO), 2005b, 2020; Macarthur and von Holst, 2012). A cost function has even been integrated into the International Seed Testing Association (ISTA) and the EU-acknowledged methods for seed quality determination (Gregoire et al., 2002; International Organization for Standardisation (ISO), 2020; Laffont et al., 2005; Regulatory Committee of Directive 2001/18, 2020; Remund et al., 2001).

A great deal of work has been done to reduce the measurement uncertainties, and with them, litigation. However, the recent regulations aimed at reducing the $\mathrm{GMO}$ content by requiring the mass conversion of measurements made into haploid genome equivalents may increase these uncertainties at several levels and increase litigation (Corbisier et al., 2017; Corbisier and Emons, 2019; EURL-GMFF, 2019a; Rose et al., 2011; Žel et al., 2012). 
The vast uncertainties due to sampling are not considered in laboratory practices (Gy, 2004a,b).

\subsection{Standardisation of GMO detection methods}

The analytical traceability of GMOs was the first systematic application of PCR and its quantitative variations, together with the necessary international guidelines and standards (ISO 21569, 21570, 21571, 24276, 21098). This standardisation work is based on performance criteria that are still relevant, both routinely and for petitioners' supplying methods (Bertheau et al., 2002; European Network of GMO Laboratories (ENGL), 2015; International Organization for Standardisation (ISO), 2006 - ISO 24276). The ISO working group on GMOs, initiated by France, has now extended its activities to identifying varieties by the matrix approach of biomarkers (fingerprinting) (ISO/TC 34/SC 16 Horizontal methods for molecular biomarker analysis). The mutual recognition of the different variants of techniques developed by the firms is in progress through standardisation at the International Union for the Protection of New Varieties of Plants (UPOV) ${ }^{18}$ and ISO; International Organization for Standardization (ISO/TC 34/ SC 16), 2015; International Organization for Standardization (ISO), 2019a,b,c).

Variety identification by fingerprinting is an ancient practice whose principles are usable for all GMO traceability (Kwon et al., 2005; Bhargava and Sharma, 2013; Korir et al., 2013 Matsaunyane and Dubery, 2018; Singh et al., 2019a). This set of techniques addressing the nuclear genome and epigenome complements the use of organelle (chloroplast) genomes, for species and variety/cultivar identification and for marker-assisted breeding (Daniell et al., 2016; Żmieńko et al., 2011). These techniques, already implemented by the ISTA $^{19}$ laboratories, involve multi-parametric analyses of numerous molecular markers for the unambiguous identification of new GMOs. Tiling DNA chips used in plant breeding will facilitate these identifications and classifications (Anderson et al., 2016; Liu, 2007). The increasingly used techniques such as NASBA and LAMP are not the priority of standardisation, which remains a long and expensive procedure.

This lack of consideration for such techniques can also be explained by the significant changes they would entail for analytical laboratories in training, purchasing equipment, or evaluating the equivalence between PCR and these methods.

However, the accuracy of all these laboratory techniques depends on the representativity of the samples. We thus have to consider the aspects of sampling all along the supply chains.

18 Working Group on Biochemical and Molecular Techniques, and DNA-Profiling in Particular, https://www.upov.int/ meetings/en/topic.jsp?group_id=261

19 International Seed Testing Association 


\section{Sampling and supply chains coexistence issues}

\subsection{Introduction}

GMO sampling strategies are not fundamentally different from those used in other areas of quality control. They are conditioned by the size, homogeneity of the products' distribution, and the distribution of the element(s) to be detected. They also vary according to the position in the supply chains (Onori et al., 2013). The detection of small quantities of GMOs, known as LLP, ${ }^{20}$ that is, a GMO which is currently unauthorised but in imported feed or withdrawn from the market, remains a significant issue (Demeke and Perry, 2014; Demeke et al., 2014; Grohmann et al., 2014).

Homogeneous products such as seeds or products processed in large quantities have standardised sampling plans, including cost functions (Allnutt, 2006; Hochegger et al., 2016; Kobilinsky and Bertheau, 2005; Laffont et al., 2005; Remund et al., 2001). On the other hand, sampling in the field, in the framework of coexistence, or cargoes, imposes complicated and expensive sampling strategies that introduce substantial measurement uncertainties (Bancal et al., 2014; Bellocchi et al., 2009; Esbensen et al., 2012; Eurachem and CITAC, 2007; Kay and Paoletti, 2001; Minkkinen et al., 2012; Paoletti et al., 2003). Some estimates indicate sampling uncertainties in the final measurements, which are at least 100 times greater than those of the analytical ones (Gy, 1998).

The heterogeneous distribution of the elements to be detected, as for mycotoxins, increases the uncertainties, complicates sampling plans and increases costs (Armitage, 2003; Miraglia et al., 2009; Onori et al., 2013). Several commitments such as high confidence limits, low detection thresholds, and the management of withdrawn GMOs also increase costs (EURL-GMFF, 2011; European Commission, 2011a). Accordingly, some authors propose using simplified mycotoxin-specific sampling designs instead of the new complex ones.

Field sampling, especially for cross-pollinated species, is undoubtedly one of the most challenging and contentious steps (Darmency et al., 2009), It has been the subject of much work in the SIGMEA and Co-Extra research programmes because of the long-distance dissemination for open-pollinated plants (Brunet et al., 2013; Messéan et al., 2006; Sustar-Vozlic et al., 2010). Some viable pollens can spread $3 \mathrm{~km}$ for corn and more than $20 \mathrm{~km}$ for Agrostis, while many contamination points outside the fields and regrowth in agricultural sites make it challenging to manage pollen and kernel flows. Finally, GMO production areas shall be kept outside of regions with wildtype relatives, such as Beta maritima, genetic resources, or the production of hybrid varieties (Aono 
et al., 2006; Bailleul et al., 2016; Busi and Powles, 2016; Emberlin et al., 1999; Rousseau et al., 2006; Snow, 2012). There are no reliable sampling plans for such particularities. Accordingly, some authors recommend using simplified sampling plans and postponing the GMO content assessment to the storage at the exit of the field. All these difficulties, complicated agricultural practices and crop rotations, with the absence of register and coordination organisms, have led to the recommendation to restrict GM crops in areas dedicated to the opposite of flexible coexistence, based on farming neighbours' negotiations (Bertheau, 2012, 2013; Czarnak-Kłos and Rodríguez-Cerezo, 2010; Rizov and Rodriguez-Cerezo, 2015; Rizov and Rodriguez Cerezo, 2014).

A land-sharing vs land-sparing option is similarly openly debated about biodiversity preservation, for instance, in natural parks.

\subsection{Sampling techniques}

A best practices-based sample preparation is as essential for GMOs as it is for other testing in traceability systems. It must routinely allow for practical limits of detection (LOD) and quantification (LOQ) to be reached, without increasing measurement uncertainties (European Network of GMO Laboratories (ENGL), 2011). The reliability of any analysis is based on the representativeness of the portion of the sample that is tested (Pitard, 2019). The reduction of the bulk samples via homogenisation and then to the test portion is a laborious, often contaminating procedure, and a source of measurement uncertainties, for which guidelines have been defined (Berben et al., 2014). The laboratories initially faced many practical problems regarding volumes and masses that could be processed quickly with easily cleanable mixing and grinding equipment. In any case, the extraction of fast, cheap and free DNA of the maximum amount of amplification inhibitors remains a challenge, both in terms of the reliability of the results and the cost involved.

The cost and unreliability of field sampling may lead to recommendations for simplified plans that are cheaper, even if they are less reliable, which means that sampling may be postponed until harvest and move towards the silos (Bailleul et al., 2016; Bannert, 2006; Miraglia et al., 2009). Long-distance dissemination of viable pollen (more than $20 \mathrm{~km}$ for some) is probably more important than initially estimated (Brunet et al., 2013; Heuberger et al., 2010; Rousseau et al., 2006). Such field sampling difficulties are exacerbated by the statistical power and suspected contamination that could be reached. For example, the sizes of required samples for a $95 \%$ confidence limit of detection would be:

- 100 plants at $3 \%$ contamination level.

- 200 plants at $1.5 \%$ contamination level. 
- 300 plants at $1 \%$ contamination level.

- 3000 plants at $0.1 \%$ contamination level. Such a practical threshold is generally targeted for avoiding labelling of technically unavoidable or fortuitous presence at the $0.9 \% \mathrm{GMO}$ legal threshold.

Even if sample-pooling strategies make it possible to reduce the number of samples tested in the first instance, the limits of laboratories and collectors are very quickly reached. These difficulties explain the many precautions taken in seed production, such as exclusion zones for the production of maize or sugar beet hybrid seeds, and the numerous GMO seed contaminations observed over the years.

Due to the difficulties in the field sampling of open-pollinated crops, the arrival of materials at the storage silo can be the first opportunity to carry out testing for the presence of GMOs. The samples taken by probes are typically used to analyse the incoming material. Specific procedures are required to analyse large products, such as beets, for pooled analyses. While immunoassays are still used for their relative cost, they lose ground to PCR and alternative methods, for instance, the detection of several GMOs with mobile PCR instruments and direct quantification. Isothermal techniques can replace PCR, mostly when deep-stick or flocculation formats have been adapted to facilitate their use. The storage in silos often allows a reduction in GMO contents in a given batch by illegal mixing of the contents. Leaving the storage facilities is probably the most critical step for export and industrial processing stages. It is the object of the most significant precautions to prevent cross-contamination.

Only a few tests are carried out downstream, because most firms rely on hazard analysis critical control point (HACCP) approaches to avoid contamination. For several decades, governments have favoured organisations' self-monitoring to disengage themselves, while the governments' enforcement services, facing their increasingly reduced means, have to endorse these sources of adulteration with documentary traceability, unless there is suspicion of contamination or presence (Davison and Bertheau, 2008; Dwinger et al., 2007). The underlying reasoning of such self-monitoring is that a firm's reputation takes a long time to establish, whereas the mistrust induced by fraud takes a long time to redress. Therefore, analytical checks are only carried out in severe doubt or emergency cases such as those determined by the MS' RASFF ${ }^{21}$ network. It is likely that after an initial challenge phase in the detection of NBT products, where operators are testing the willingness of MS to implement the decision of the ECJ, the same documentary traceability-based enforcement strategy will prevail for NBT products. 


\section{Conclusion}

This chapter has considered the technical advances developed to identify transgenic GMOs and assure the traceability of GMOs in food supply chains. The use of different targets and signal amplification of variants, with or without hybridisation, makes available a range of qualitative and quantitative methods (QRT-PCR, LAMP, NASBA, LCR, SNPLex...) that can be chosen, depending on the target. These methodological approaches can be applied from the field to the laboratory, from point mutation to the junction sequence between rearranged elements and from single to multiple targets (Bertheau, 2013; Bertheau, 2019; Chhalliyil et al., 2020). Associated with various decision support tools, they allow, via the matrix approach, the identification of any GMO. Most of the methods and guidelines necessary for the analytical traceability of GMOs in the supply chains are available on the EURL-GMFF website. ${ }^{22}$

The implementation of GMO traceability systems is a techno-political decision, subject to many pressures. Changing the definition of GMOs or the measurement unit in the future will only reinforce citizens' mistrust in politicians, administrations, and researchers interested in these techniques. As noted in the recent ENGL report(ENGL, 2019), the current EU regulations, with their mandatory requirement for the supply of reference materials and biomarkers such as those used in varietal identification, would, with some probable adjustments, mostly suffice to ensure their traceability, whatever the method of obtaining them.

Techniques to detect all kinds of molecular targets, like 'hidden' and 'new' GMOs, are available. The issues of detection and identification, such as defining targets and routine methods for those GMOs, are considered in more depth in the next chapter.

\section{Where to look for further information}

The book resulting from the Co-Extra European research program gives an overview of the problems and solutions concerning the traceability and coexistence of GMO and non-GMO supply chains (https://onlinelibrary.wiley .com/doi/book/10.1002/9781118373781).

The site of the European GMO reference laboratory and the ENGL network provides the majority of references necessary for any analytical practice in GMO detection (https://gmo-crl.jrc.ec.europa.eu/).

Louis Pasteur (1822-1895) professed: "Have the cult of the critical spirit. Reduced to itself, it is neither an awakener of ideas, nor a stimulant of great things. Without it, everything is null and void", so in the face of the assertions of the economy of the promise of firms, please consider carefully sites like this one: https://www.gmwatch.org/en/. 


\section{References}

Aerni, P. (2019). Politicizing the precautionary principle: why disregarding facts should not pass for farsightedness. Frontiers in Plant Science 10, 1053. https://www.frontiersin. org/articles/10.3389/fpls.2019.01053/full.

Alonge, M., Wang, X., Benoit, M., Soyk, S., Pereira, L., Zhang, L., Suresh, H., Ramakrishnan, S., Maumus, F., Ciren, D., Levy, Y., Harel, T. H., Shalev-Schlosser, G., Amsellem, Z., Razifard, H., Caicedo, A. L., Tieman, D. M., Klee, H., Kirsche, M., Aganezov, S., RanalloBenavidez, T. R., Lemmon, Z. H., Kim, J., Robitaille, G., Kramer, M., Goodwin, S., McCombie, W. R., Hutton, S., Van Eck, J., Gillis, J., Eshed, Y., Sedlazeck, F. J., van der Knaap, E., Schatz, M. C. and Lippman, Z. B. (2020). Major impacts of widespread structural variation on gene expression and crop improvement in tomato. Cell 182(1), 145-161.

Allnutt, T. (2006). A Combined Protocol for PCR Detection of GM in Seed. (Central Science Laboratory), p. 10. http://www.gm-inspectorate.gov.uk/documents/COPsFinalRe portweb.pdf.

Altpeter, F., Springer, N. M., Bartley, L. E., Blechl, A. E., Brutnell, T. P., Citovsky, V., Conrad, L. J., Gelvin, S. B., Jackson, D. P., Kausch, A. P., Lemaux, P. G., Medford, J. I., OrozcoCárdenas, M. L., Tricoli, D. M., Van Eck, J., Voytas, D. F., Walbot, V., Wang, K., Zhang, Z. J. and Stewart, C. N. (2016). Advancing crop transformation in the era of genome editing. The Plant Cell 28(7), 1510-1520.

Anderson, J. E., Michno, J. M., Kono, T. J. Y., Stec, A. O., Campbell, B. W., Curtin, S. J. and Stupar, R. M. (2016). Genomic variation and DNA repair associated with soybean transgenesis: a comparison to cultivars and mutagenized plants. BMC Biotechnology 16(1), 41.

Angers-Loustau, A., Petrillo, M., Bonfini, L., Gatto, F., Rosa, S., Patak, A. and Kreysa, J. (2014). JRC GMO-Matrix: a web application to support genetically modified organisms detection strategies. BMC Bioinformatics 15, 417.

Anklam, E., Gadani, F., Heinze, P., Pijnenburg, H. and Van Den Eede, G. (2002). Analytical methods for detection and determination of genetically modified organisms in agricultural crops and plant-derived food products. European Food Research and Technology 214(1), 3-26.

Aono, M., Wakiyama, S., Nagatsu, M., Nakajima, N., Tamaoki, M., Kubo, A. and Saji, H. (2006). Detection of feral transgenic oilseed rape with multiple-herbicide resistance in Japan. Environmental Biosafety Research 5(2), 77-87.

Armitage, D. (2003). Grain sampling methods to achieve consumer confidence and food safety. In HGCA Research Review, CSL DEFRA. (DEFRA, Sand Hutton, UK: AHDB Cereals \& Oilseeds), p. 36.

Bailleul, D., Ollier, S. and Lecomte, J. (2016). Genetic diversity of oilseed rape fields and feral populations in the context of coexistence with GM crops. PLoS ONE 11(6), e0158403.

Balestrazzi, A., Yoshiyama, K. O. and Sakamoto, A. N. (2020). Editorial: the maintenance of genome integrity in plants: novel challenges in basic and applied research. Frontiers in Plant Science 11, 585.

Bancal, R., Bensadoun, A., Messéan, A., Monod, H. and Makowski, D. (2014). Comparison of sampling strategies to evaluate rate of transgenic adventitious presence in agricultural fields. AgBioForum 17, 166-171. 
Bannert, M. (2006). Simulation of transgenic pollen dispersal by use of different grain colour maize. Diss. ETH No. 16508. Institute of Plant Sciences Group Agronomy and Plant Breeding. (Zürich, Switzerland: Swiss Federal Institute of Technology), p. 92.

Bellocchi, G., Ermolli, M., Savini, C. and Eede, G. V. D. (2009). GMO testing methods: analytical approaches, method validation and sampling strategy. In: The ICC handbook of cereals, flour, dough and product testing: methods and applications Cauvain, S. and Young, L. (Eds). (DEStech Publications Inc.), pp. 279-289. https://pu blications.jrc.ec.europa.eu/repository/handle/JRC43668.

Bellocchi, G., Savini, C., Van den Bulcke, M., Mazzara, M. and Van den Eede, G. (2010). Fuzzy logic-based procedures for GMO analysis. Accreditation and Quality Assurance 15(11), 637-641.

Berben, G., Charels, D., Demsar, T., Hochegger, R., Nardini, E., Onori, R., Schulze, M., Philipp, P. and Weber, T. (2014). Guidelines for Sample Preparation Procedures in GMO Analysis JRC94042. (Luxembourg: Publications Office of the European Union), p. 42.

Bertheau, Y. (2002). Elaboration d'un référentiel scientifique et technique permettant de caractériser les produits agricoles et alimentaires garantis sans OGM. Programme "Pertinence économique et faisabilité d'une filière "sans utilisation d'OGM »" (INRA, Paris, France), p. 48.

Bertheau, Y. (2012). OGM: de la traçabilité et de la coexistence des filières à l'aménagement du territoire / GMO: from supply chain traceability and coexistence to territory management. Territoire en Mouvement 12, 56-80.

Bertheau, Y. (Eds.) (2013). Genetically Modified and Non-Genetically Modified Food Supply Chains: Co-Existence and Traceability. (Wiley-Blackwell), p. 698. https://on linelibrary.wiley.com/doi/book/10.1002/9781118373781.

Bertheau, Y. (2019). New breeding techniques: detection and identification of the techniques and derived products. In: Encyclopedia of Food Chemistry, Reference Module in Food Science Stadler, R. H. (Ed). (Elsevier), pp. 320-336. https://www.sci encedirect.com/science/article/pii/B9780081005965218349.

Bertheau, Y. and Davison, J. (2013). Introduction to the GM and non-GM supply chain co-existence and traceability. In: Genetically Modified and Non-Genetically Modified Food Supply Chains: Co-Existence and Traceability Bertheau, Y. (Ed). (WileyBlackwell), pp. 1-20. https://onlinelibrary.wiley.com/doi/abs/10.1002/9781118 373781.ch1.

Bertheau, Y., Diolez, A., Kobilinsky, A. and Magin, K. (2002). Detection methods and performance criteria for genetically modified organisms. Journal of AOAC International 85(3), 801-808.

Bertheau, Y. and Kobilinsky, A. (2004). Detection of GMOs. In: Viruses and Virus Diseases of Poaceae (Gramineae) Lapierre, H. and Signoret, P. A. (Eds). (Editions Quae), pp. 249-270. https://www.quae.com/produit/598/9782759215829/viruses-and-virusdiseases-of-poaceae-gramineae .

Bey, T., Jamge, S., Klemme, S., Komar, D. N., Le Gall, S., Mikulski, P., Schmidt, M., Zicola, J. and Berr, A. (2016). Chromatin and epigenetics in all their states: meeting report of The first conference on Epigenetic and chromatin Regulation of Plant Traits-January 14-15, 2016-Strasbourg, France. Epigenetics 11(8), 625-634.

Bhargava, M. and Sharma, A. (2013). DNA barcoding in plants: evolution and applications of in silico approaches and resources. Molecular Phylogenetics and Evolution 67(3), 631-641. 
Block, A., Debode, F., Grohmann, L., Hulin, J., Taverniers, I., Kluga, L., Barbau-Piednoir, E., Broeders, S., Huber, I., Van den Bulcke, M., Heinze, P., Berben, G., Busch, U., Roosens, N., Janssen, E., Žel, J., Gruden, K. and Morisset, D. (2013). The GMOseek matrix: a decision support tool for optimizing the detection of genetically modified plants. BMC Bioinformatics 14, 1-14.

Bodulev, O. L. and Sakharov, I. Y. (2020). Isothermal nucleic acid amplification techniques and their use in bioanalysis. Biochemistry Biokhimiia 85(2), 147-166.

Bohanec, M., Bertheau, Y., Brera, C., Gruden, K., Holst-Jensen, A., Kok, E. J., Lécroart, B., Messéan, A., Miraglia, M., Onori, R., Prins, T. W., Soler, L-G. and Žnidaršič, M. (2013). The Co-Extra decision support system: a model-based integration of project results. In: Genetically Modified and Non-Genetically Modified Food Supply Chains: Co-Existence and Traceability Bertheau, Y. (Ed). (Wiley-Blackwell), pp. 461-490. https://onlinelibrary .wiley.com/doi/10.1002/9781118373781.ch25.

Bonfini, L., Angers-Loustau, A., Petrillo, M., Ciabatti, I., Gatto, F., Rosa, S., Lievens, A. and Kreysa, J. (2016). Chapter 24.The European Union reference methods database and decision supporting tool for the analysis of Genetically Modified Organisms: GMOMETHODS and JRC GMO-Matrix. In: Genetically Modified Organisms in Food Preedy, V. R. and Watson, R. R. (Eds). (San Diego: Academic Press), pp. 275 $-288$.

Bonfini, L., Heinze, P., Kay, S. and van den Eede, G. (2002). Review of GMO Detection and Quantification Techniques. EUR 20384/EN, p. 67.

Brash, D. E. and Hart, R.W.(1978). DNA damage and repair in vivo. Journal of Environmental Pathology and Toxicology 2(1), 79-114.

Bratspies, R. M. (2003). Myths of voluntary compliance: lessons from the Starlink corn fiasco. SSRN Electronic Journal 27, 591-647.

Breyer, D., Herman, P., Brandenburger, A., Gheysen, G., Remaut, E., Soumillion, P., Doorsselaere, J. v., Custers, R., Pauwels, K., Sneyers, M. and Reheul, D. (2009). Genetic modification through oligonucleotide-mediated mutagenesis: a GMO regulatory challenge? Environmental Biosafety Research 8(2), 57-64.

Broothaerts, W., Cordeiro, F., Robouch, P. and Emons, H. (2020). Ten years of proficiency testing reveals an improvement in the analytical performance of EU National Reference Laboratories for genetically modified food and feed. Food Control 114, 107237.

Brunet, Y., Dupont, S., Delage, S., Garrigou, D., Guyon, D., Dayau, S., Tulet, P., Pinty, J.P., Lac, C., Escobar, J., Audran, A. and Foueillassar X. (2013). Long-distance pollen flow in large fragmented landscapes. In: Genetically Modified and Non-Genetically Modified Food Supply Chains: Co-Existence and Traceability Bertheau, Y. (Ed). (Wiley-Blackwell), pp. 79-88. https://onlinelibrary.wiley.com/doi/10.1002/978111 8373781.ch6.

Burgos, N. R. (2015). Whole-plant and seed bioassays for resistance confirmation. Weed Science 63(SP1), 152-165.

Burian, A., Barbier de Reuille, P. and Kuhlemeier, C. (2016). Patterns of stem cell divisions contribute to plant longevity. Current Biology: CB 26(11), 1385-1394.

Busi, R. and Powles, S. B. (2016). Transgenic glyphosate-resistant canola (Brassica napus) can persist outside agricultural fields in Australia. Agriculture, Ecosystems and Environment 220, 28-34.

Cankar, K., Chauvensy-Ancel, V., Fortabat, M. N., Gruden, K., Kobilinsky, A., Zel, J. and Bertheau, Y. (2008). Detection of nonauthorized genetically modified organisms 
using differential quantitative polymerase chain reaction: application to $35 \mathrm{~S}$ in maize. Analytical Biochemistry 376(2), 189-199.

Caprioara-Buda, M., Meyer, W., Jeynov, B., Corbisier, P., Trapmann, S. and Emons, H. (2012). Evaluation of plasmid and genomic DNA calibrants used for the quantification of genetically modified organisms. Analytical and Bioanalytical Chemistry 404(1), 29-42.

Chaouachi, M., Giancola, S., Kobilinsky, A., Ayadi, M., Haen, S., Duplan-Fortabat, M.-N., Audéon, C., Couture, C., Romaniuk, M., Ancel, V., Bartegi, A., Brunel, D. and Bertheau Y. (2005). Detection of approved and unapproved GMO by the "matrix approach". Paper presented at: Second International Conference on Co-Existence Between GM and non-GM Based Agricultural Supply Chain (GMCC, Montpellier, France: Agropolis Editions).

Chen, Y. X., Huang, K. J. and Niu, K. X. (2018). Recent advances in signal amplification strategy based on oligonucleotide and nanomaterials for microRNA detection-a review. Biosensors and Bioelectronics 99, 612-624.

Chhalliyil, P., Ilves, H., Kazakov, S. A., Howard, S. J., Johnston, B. H. and Fagan, J. (2020). A real-time quantitative PCR method specific for detection and quantification of the first commercialized genome-edited plant. Foods 9(9), 1245.

Comité Européen de Normalisation (CEN) (2014). Foodstuffs-methods of analysis for the detection of genetically modified organisms and derived products-polymerase chain reaction (PCR) based screening strategies prCEN/TS 16707, p. 21.

Commission of the European Communities (1992). Interpretation of the concept "Traditional breeding" in the context of the exemption outlined in Annexes I B of Directives 90/219/EC and 90/220/EC, N.S. Directorate General. Environment, and Civil Protection. DC XI/A/2, ed. (Brussels, Belgium: Commission of the European Communities), p. 37.

Conseil d'État (2020). Décision contentieuse-Communiqué de presse-Certains organismes obtenus par mutagenèse doivent respecter la réglementation OGMCONSEIL D'ÉTAT statuant au contentieux No 388649, Conseil d'État, ed. (Paris, France: République française).

Corbisier, P., Barbante, A., Berben, G., Broothaerts, W., De Loose, M., Emons, H., Georgieva, T., Lievens, A., Mazzara, M., Papazova, N., et al. (2017). Recommendation for the Unit of Measurement and the Measuring System to Report Traceable and Comparable Results Expressing G.M. Content in Accordance with EU Legislation. (Luxemburg: Joint Research Center), p. 36.

Corbisier, P. and Emons, H. (2019). Towards metrologically traceable and comparable results in G.M. quantification. Analytical and Bioanalytical Chemistry 411(1), 7-11.

Corrado, G. (2016). Advances in DNA typing in the agro-food supply chain. Trends in Food Science \& Technology 52, 80-89.

Czarnak-Kłos, M. and Rodríguez-Cerezo, E. (2010). European Coexistence Bureau (ECoB). Best Practice Documents for coexistence of genetically modified crops with conventional and organic farming. 1. Maize crop production. EUR 24509 EN. In JRC Scientific and Technical Reports, DG-JRC-IPTS, ed. (Seville, Spain: DG-JRC-IPTS), pp. $72 .$.

Daniell, H., Lin, C. S., Yu, M. and Chang, W. J. (2016). Chloroplast genomes: diversity, evolution, and applications in genetic engineering. Genome Biology 17(1), 134-134.

Darmency, H., Klein, E. K., De Garanbe, T. G., Gouyon, P. H., Richard-Molard, M. and Muchembled, C. (2009). Pollen dispersal in sugar beet production fields. Theoretical and Applied Genetics 118, 1083-1092. 
Davison, J. and Bertheau, Y. (2007). EU regulations on the traceability and detection of GMOs: difficulties in interpretation, implementation and compliance. CAB Reviews: Perspectives in Agriculture, Veterinary Science, Nutrition and Natural Resources 2(77), 124.

Davison, J. and Bertheau, Y. (2008). The theory and practice of European traceability regulations for G.M. food and feed. Cereal Foods World 53, 186-196.

Davison, J. and Bertheau, Y. (2009). Key issues and open questions in GMO controls. In: Global Issues in Food Science and Technology Barbosa-Cánovas, G., Mortimer, A., Lineback, D., Spiess, W., Buckle, K. and Colonna, P. (Eds). (Pullman, WA: Washington State University Press), pp. 353-365.

Demeke, T., and Jenkins, G. R. (2010). Influence of DNA extraction methods, PCR inhibitors and quantification methods on real-time PCR assay of biotechnology-derived traits. Analytical and Bioanalytical Chemistry 396, 1977-1990.

Demeke, T. and Perry, D. J. (2014). Low-Level Presence of unapproved biotech materials: current status and capability of DNA-based detection methods. Canadian Journal of Plant Science 94(3), 497-507.

Demeke, T., Phan, A., Ratnayaka, I., Holigroski, M. and Jenkins, G. R. (2014). Influence of amount of starting material for DNA extraction on detection of Low-Level Presence of genetically engineered traits. Journal of Agricultural and Food Chemistry 62(19), 4349-4358.

Demestichas, K., Peppes, N., Alexakis, T. and Adamopoulou, E. (2020). Blockchain in agriculture traceability systems: a review. Applied Sciences 10(12), 4113.

Demortain, D. (2011). Scientists and the Regulation of Risk: Standardising Control. (Cheltenham UK, Northhampton, MA: Edward Elgar Publishing).

Deprez, L., Corbisier, P., Kortekaas, A. M., Mazoua, S., Beaz Hidalgo, R., Trapmann, S. and Emons, H. (2016). Validation of a digital PCR method for quantification of DNA copy number concentrations by using a certified reference material. Biomolecular Detection and Quantification 9, 29-39.

Diaz, C., Fernandez, C., McDonald, R. and Yeung, J. M. (2002). Determination of Cry9C protein in processed foods made with StarLink corn. Journal of AOAC International 85(5), 1070-1076.

Dix, P. J. (1994). Isolation and characterisation of mutant cell lines. In: Plant Cell and Tissue Culture Vasil, I. K. and Thorpe, T. A. (Eds). (Dordrecht: Springer Netherlands), pp. 119-138.

Dong, W., Yang, L. T., Shen, K. L., Kim, B., Kleter, G. A., Marvin, H. J. P., Guo, R., Liang, W. Q. and Zhang, D. B. (2008). GMDD: a database of GMO detection methods. BMC Bioinformatics 9, 260.

Dwinger, R. H., Golden, T. E., Hatakka, M. and Daelman, W. (2007). The "Hygiene Package"-A new approach to food safety. In: ISAH-2007. (Tartu, Estonia: ISAH), pp. 24-30. https://www.isah-soc.org/userfiles/downloads/proceedings/Proc_ISAH_200 7_Volume_l/04_Dwinger.pdf.

Edmondson, R., Broglie, J. J., Adcock, A. F. and Yang, L. (2014). Three-dimensional cell culture systems and their applications in drug discovery and cell-based biosensors. Assay and Drug Development Technologies 12(4), 207-218.

Emberlin, J., Adams-Groom, B. and Tidmarsh, J. (1999). A report on the dispersal of maize pollen (commissioned by SOIL ASSOCIATION), p. 22.

Ellstrand, N. C. (2003). Going to "great lengths" to prevent the escape of genes that produce specialty chemicals. Plant Physiology 132(4), 1770-1774. 
Esbensen, K. H., Paoletti, C. and Minkkinen, P. (2012). Representative sampling of large kernel lots I. Theory of Sampling and variographic analysis. TrAC Trends in Analytical Chemistry 32, 154-164.

Eurachem, and CITAC, eds. (2007). Measurement uncertainty arising from sampling. A guide to methods and approaches. Produced jointly with Eurolab, Nordtest and the UK TSC Analytical Methods Committee (Eurachem CITAC), p. 111.

EURL-GMFF (2011). Technical guidance document from the European Union Reference Laboratory for genetically modified food and feed on the implementation of Commission regulation (EC) No 619/2011, JRC-IHCP, ed. (Ispra, Italy: Joint Research Centre), pp. 6.

EURL-GMFF (2019a). Use of the harmonised conversion factors to transform PCR results from the DNA copy number ratio domain into the mass fraction domain. In Application Note (Ispra, Italy: Joint Research Center), p. 2.

EURL-GMFF (2019b). Parameters and acceptance criteria to verify the appropriateness of GMO certified reference materials (Joint Research Centre), p. 4.

European Commission (1997). Regulation (EC) No 258/97 of the European Parliament and of the Council of 27 January 1997 concerning novel foods and novel food ingredients. No longer in force, Date of end of validity: 31/12/2017. Official Journal of the European Communities L 043, 1-6.

European Commission (2000a). Commission regulation (EC) No 49/2000 of 10 January 2000 amending Council Regulation (EC) No 1139/98 concerning the compulsory indication on the labelling of certain foodstuffs produced from genetically modified organisms of particulars other than those provided for in Directive 79/112/EEC. Official Journal of the European Communities L 6, 13-14.

European Commission (2000b). Regulation (EC) No 50/2000 of 10 January 2000 on the labelling of foodstuffs and food ingredients containing additives and flavourings that have been genetically modified or have been produced from genetically modified organisms. Official Journal of the European Communities L 6, 15-17.

European Commission (2001). White Paper: Strategy for a Future Chemicals PolicyC.O.M. (2001) 88 final-27.02.2001, D.G. Enterprise and Industry, ed. (European Commission).

European Commission (2002). Regulation (EC) No 178/2002 of the European Parliament and of the Council of 28 January2002 laying down the general principles and requirements of food law, establishing the European Food Safety Authority and laying down procedures in matters of food safety. Official Journal of the European Communities L 31, 1-24.

European Commission (2003a). Commission Recommendation of 23 July 2003 on guidelines for the development of national strategies and best practices to ensure the co-existence of genetically modified crops with conventional and organic farming (notified under document number C(2003) 2624). (2003/556/C.E.). Official Journal of the European Communities L 189, 36-47.

European Commission (2003b). Regulation (EC) No 1829/2003 of the European Parliament and of the Council of 22 September 2003 on genetically modified food and feed (Text with EEA relevance). Official Jounal of the European Communities L $268,1-23$.

European Commission (2003c). Regulation (EC) No 1830/2003 of the European Parliament and of the Council of 22 September 2003 concerning the traceability and labelling of genetically modified organisms and the traceability of food and feed 
products produced from genetically modified organisms and amending Directive 2001/18/EC. Official Journal of the European Union L 268, 24-28.

European Commission (2004). Commission recommendation No 2004/787 of 4 october 2004 on technical guidance for sampling and detection of genetically modified organisms as or in products in the context of Regulation (EC) No 1830/2003. Official Journal of the European Union L 348, 18-26.

European Commission (2006a). Commission staff working document-annex to the communication from the commission to the council and the European Parliamentreport on the implementation of national measures on the co-existence of genetically modified crops with conventional and organic farming (European Commission). SEC/2006/0313.

European Commission (2006b) Communication from the Commission to the Council and the European Parliament. Report on the implementation of national measures on the co-existence of genetically modified crops with conventional and organic farming. (European Commission). COM 2006/0104 final, pp. 10.

European Commission (2006c). Commission Regulation (EC) No 1981/2006 of 22 December 2006 on detailed rules for the implementation of Article 32 of Regulation (EC) No 1829/2003 of the European Parliament and of the Council as regards the Community reference laboratory for genetically modified organisms (Text with EEA relevance). Official Jounal of the European Union L 368, 99-103.

European Commission (2009). Commission Regulation (EC) No 152/2009 of 27 January 2009 laying down the methods of sampling and analysis for the official control of feed (Text with EEA relevance). Official Journal of the European Union L 54, 1-130.

European Commission (2010). A decade of EU-funded GMO research (2001-2010). EUR 24473, European Commission, ed. (Brussels, Belgium: European Commission,), p. 264.

European Commission (2011a). Commission Regulation (EU) No 619/2011 of 24 June 2011 laying down the methods of sampling and analysis for the official control of feed as regards presence of genetically modified material for which an authorisation procedure is pending or the authorisation of which has expired (Text with EEA relevance). Official Journal of the European Union L 166, 9-15.

European Commission (2011b). Report from the Commission to the European parliament and the Council on socio-economic implications of GMO cultivation on the basis of Member States contributions, as requested by the Conclusions of the Environment Council of December 2008, DG-Sanco European Commission, ed. (Brussels, Belgium), p. 11.

European Commission (2013). Commission implementing regulation (EU) No 503/2013 of 3 April 2013 on applications for authorisation of genetically modified food and feed in accordance with Regulation (EC) No 1829/2003 of the European Parliament and of the Council and amending Commission Regulations (EC) No 641/2004 and (EC) No 1981/2006. Official Journal of the European Union L 157, 1-48.

European Commission (2015a). Directive (EU) 2015/412 of the European Parliament and of the Council of 11 March 2015 amending Directive 2001/18/EC as regards the possibility for the Member States to restrict or prohibit the cultivation of genetically modified organisms (GMOs) in their territory. Official Journal of the European Union L 68, 1-8.

European Commission (2015b). Regulation (EU) 2015/2283 of the European Parliament and of the Council of 25 November 2015 on novel foods, amending Regulation 
(EU) No 1169/2011 of the European Parliament and of the Council and repealing Regulation (EC) No 258/97 of the European Parliament and of the Council and Commission Regulation (EC) No 1852/2001 (Text with EEA relevance). Official Journal of the European Union L 327, 1-22.

European Commission (2018). Commission Directive (EU) 2018/350 of 8 March 2018 amending Directive 2001/18/EC of the European Parliament and of the Council as regards the environmental risk assessment of genetically modified organisms. Official Journal of the European Union L67, 30-45.

European Court of Justice (2018). Organisms obtained by mutagenesis are GMOs and are, in principle, subject to the obligations laid down by the GMO Directive. Press Release 111/18 (Luxembourg: European Court of Justice).

European Food Safety Authority (EFSA), Bahadori, T., Bell, D., Ceccatelli, S., Corvi, R., Hogstrand, C., Munn, S., Nilsson, E., Spurgeon, D., Vom Brocke, J., Wright, M., Binaglia, M., Dorne, J-L., Georgiadis, N., Germini, A., Kass, G., Robinson, T., Rossi, A., Schoonjans, R., Terron, A. and Noteborn, H. (2016). EFSA Scientific Colloquium 22-Epigenetics and risk assessment: where do we stand? EFSA Supporting Publications 13, 1129E.

European Network of GMO Laboratories (ENGL) (2011). Verification of analytical methods for GMO testing when implementing interlaboratory validated methods. Guidance document from the European Network of GMO laboratories (ENGL). Prepared by the ENGL working group on "Method Verification". In JRC Scientific and Technical Reports, Joint Research Centre, ed. (Ispra, Italy: Joint Research Centre of the European Commission), pp. 27.

European Network of GMO Laboratories (ENGL) (2015). Definition of minimum performance requirements for analytical methods of GMO testing, pp. 24 pp. In: JRC Technical Report.

European Network of GMO Laboratories (ENGL) (2019). Detection of food and feed plant products obtained by new mutagenesis techniques (JRC116289) (Luxemburg) European Commission, Joint Research Centre, pp. 21.

European Parliament and European Council (2019). Regulation (EU) 2019/1381 of the European Parliament and of the Council of 20 June 2019 on the transparency and sustainability of the EU risk assessment in the food chain and amending Regulations (EC) No 178/2002, (EC) No 1829/2003, (EC) No 1831/2003, (EC) No 2065/2003, (EC) No 1935/2004, (EC) No 1331/2008, (EC) No 1107/2009, (EU) 2015/2283 and Directive 2001/18/EC (Text with EEA relevance.). Official Journal of the European Union L231/1, 28.

Fehér, A. and Dudits, D. (1994). Plant protoplasts for cell fusion and direct DNA uptake: culture and regeneration systems. In: Plant Cell and Tissue Culture Vasil, I. K. and Thorpe, T. A. (Eds). (Dordrecht: Springer Netherlands), pp. 71-118.

Fojtová, M. and Fajkus, J. (2020). Chromatin, epigenetics and plant physiology. International Journal of Molecular Sciences 21(8), 2763.

Fraiture, M. A., Herman, P., Taverniers, I., De Loose, M., Deforce, D. and Roosens, N. H. (2015). Current and new approaches in GMO detection: challenges and solutions. BioMed Research International 2015, 392872.

Franco, I., Helgadottir, H. T., Moggio, A., Larsson, M., Vrtačnik, P., Johansson, A., Norgren, N., Lundin, P., Mas-Ponte, D., Nordström, J., Lundgren, T., Stenvinkel, P., Wennberg, L., Supek, F. and Eriksson, M. (2019). Whole genome DNA sequencing provides an atlas of somatic mutagenesis in healthy human cells and identifies a tumor-prone cell type. Genome Biology 20(1), 285. 
Friedrichs, S., Takasu, Y., Kearns, P., Dagallier, B., Oshima, R., Schofield, J. and Moreddu, C. (2019a). Meeting report of the OECD conference on "genome editing: applications in agriculture-implications for health, environment and regulation". Transgenic Research 28, 419-463.

Friedrichs, S., Takasu, Y., Kearns, P., Dagallier, B., Oshima, R., Schofield, J. and Moreddu, C. (2019b). An overview of regulatory approaches to genome editing in agriculture. Biotechnology Research and Innovation 3(2), 208-220.

Fumiere, O., Veys, P., Boix, A., von Holst, C., Baeten, V. and Berben, G. (2009). Methods of detection, species identification and quantification of processed animal proteins in feedingstuffs. Biotechnology, Agronomy and Society and Environment 13, 59-70.

GAIN USDA (2021). Agricultural biotechnology annual. In Biotechnology and Other New Production Technologies, USDA, and GAIN, eds. (Brussels, Belgium), pp. 37.

GAO (US Government Accountability Office) (2008). Agencies are proposing changes to improve oversight, but could take additional steps to enhance coordination and monitoring. In Report to the Committee on Agriculture, Nutrition, and Forestry, US Senate (US Government Accountability Office), pp. 109.

GAO (US Government Accountability Office) (2016a). Report to the Honorable Jon Tester, US Senate. Genetically engineered crops. USDA needs to enhance oversight and better understand impacts of unintended mixing with other crops, pp. 71.

GAO (US Government Accountability Office) (2016b). Genetically Engineered Crops: USDA needs to enhance oversight and better understand impacts of unintended mixing with other crops, pp. 71.

Garcia, P. R. (2006). Directive 2001/18/EC on the deliberate release into the environment of GMOs: an overview and the main provisions for placing on the market. Journal for European Environmental and Planning Law 3(1), 3-12.

Gaskell, G., Allum, N., Wagner, W., Kronberger, N., Torgersen, H., Hampel, J. and Bardes, J. (2004). GM foods and the misperception of risk perception. Risk Analysis: An Official Publication of the Society for Risk Analysis 24(1), 185-194.

Gavazzi, G., Tonelli, C., Todesco, G., Arreghini, E., Raffaldi, F., Vecchio, F., Barbuzzi, G., Biasini, M. G. and Sala, F. (1987). Somaclonal variation versus chemically induced mutagenesis in tomato (Lycopersicon esculentum L.). TAG. Theoretical and Applied Genetics. Theoretische und Angewandte Genetik 74(6), 733-738.

Gerdes, L., Busch, U. and Pecoraro, S. (2012a). GMOfinder - A GMO screening database. Food Analytical Methods 5, 1368-1376.

Gregoire, S., Laffont, J. L. and Remund, K. (2002). Robust seed sampling plans for GM adventitious presence testing. ISTA News Bulletin 124, 12-14.

Gregory, B. D., Yazaki, J. and Ecker, J. R. (2008). Utilizing tiling microarrays for wholegenome analysis in plants. The Plant Journal: For Cell and Molecular Biology 53(4), 636-644.

Grohmann, L., Belter, A., Speck, B., Westphal, K., Näumann, G., Hess, N. and Bendiek, J. (2014). Collaborative trial validation of a testing plan for detection of low level presence of genetically modified seeds. Seed Science and Technology 42(3), 414-432.

Grothaus, G. D., Bandla, M., Currier, T., Giroux, R., Jenkins, G. R., Lipp, M., Shan, G., Stave, J. W. and Pantella, V. (2006). Immunoassay as an analytical tool in agricultural biotechnology. Journal of AOAC International 89(4), 913-928.

Gruden, K., Allnutt, T. R., Ayadi, M., Baeumler, S., Bahrdt, C., Berben, G., Berdal, K. G., Bertheau, Y., Bøydler Andersen, C., Brodmann, P., Buh Gašparič, M., Burns, M. J., 
Burrel, A. M., Cankar, K., Esteve, T., Holst-Jensen, A., Kristoffersen, A. B., La Paz, J., Lee, D., Løvseth, A., Macarthur, R., Morisset, D., Pla, M., Rud, R. B., Skjæret, C., Tengs, T., Valdivia, H., Wulff, D., Zhang, D. and Žel, J. (2013). Reliability and cost of GMO detection. In: Genetically Modified and Non-Genetically Modified Food Supply Chains: Co-Existence and Traceability Bertheau, Y. (Ed). (Wiley), pp. 307-332. https:// onlinelibrary.wiley.com/doi/abs/10.1002/9781118373781.ch18.

Gryson, N., Ronsse, F., Messens, K., De Loose, M., Verleyen, T. and Dewettinck, K. (2002). Detection of DNA during the refining of soybean oil. Journal of the American Oil Chemists Society 79, 171-174.

Gy, P. (1998) Sampling for Analytical Purposes. (Wiley), p. 172.

Gy, P. (2004a) Sampling of discrete materials-a new introduction to the theory of sampling. Chemometrics and Intelligent Laboratory Systems 74(1), 7-24.

Gy, P. (2004b) Sampling of discrete materials. Chemometrics and Intelligent Laboratory Systems 74(1), 39-47.

Hammarlund, E. U., Flashman, E., Mohlin, S. and Licausi, F. (2020). Oxygen-sensing mechanisms across eukaryotic kingdoms and their roles in complex multicellularity. Science 370(6515), eaba3512.

Haut Conseil des Biotechnologies (HCB) (2017). Scientific Opinion on New Plant Breeding Techniques, p. 86. www.hautconseildesbiotechnologies.fr/sites/www.hautconseilde sbiotechnologies.fr/files/file_fields/2018/01/11/publicationtraductionanglaise-1 71201 aviscsnpbtfinale.pdf .

Hedman, J., Lavander, M., Salomonsson, E. N., Jinnerot, T., Boiso, L., Magnusson, B. and Rådström, P. (2018). Validation guidelines for PCR workflows in bioterrorism preparedness, food safety and forensics. Accreditation and Quality Assurance 23(3), 133-144.

Hemmer, W. (1997). Foods derived from genetically modified organisms and detection methods Agency for Biosafety Research and Assessment of Technology Impacts of the Swiss Priority Programme Biotechnology of the Swiss Science Foundation (BATS) report (Basel, Switzerland), p. 59.

Heuberger, S., Ellers-Kirk, C., Tabashnik, B. E. and Carrière, Y. (2010). Pollen- and seedmediated transgene flow in commercial cotton seed production fields. PLOS ONE 5(11), e14128.

Hiei, Y., Ishida, Y. and Komari, T. (2014). Progress of cereal transformation technology mediated by Agrobacterium tumefaciens. Frontiers in Plant Science 5, 628.

Hochegger, R., Bassani, N., Belter, A., Goerlich, O., Grohmann, L., Kreysa, J., Loose, M., Mazzara, M., Macarthur, R., Perri, E., Rajcevic, B., Rolland, M., Savini, C,. Sowa, S., Speck, B., Beekvelt, C. and Villa, D. (2016). Report of the Working Group "Seed Testing" of the European Network of GMO Laboratories (ENGL), p 48.

Hofmeister, B. T., Denkena, J., Colomé-Tatché, M., Shahryary, Y., Hazarika, R., Grimwood, J., Mamidi, S., Jenkins, J., Grabowski, P. P., Sreedasyam, A., Shu, S., Barry, K., Lail, K., Adam, C., Lipzen, A., Sorek, R., Kudrna, D., Talag, J., Wing, R., Hall, D. W., Jacobsen, D., Tuskan, G. A., Schmutz, J., Johannes, F. and Schmitz, R. J. (2020). A genome assembly and the somatic genetic and epigenetic mutation rate in a wild long-lived perennial Populus trichocarpa. Genome Biology 21(1), 259-259.

Holst-Jensen, A., Berdal, K. G., Bertheau, Y., Bohanec, M., Bohlin, J., Chaouachi, M., Gruden, K., Hamels, S., Kok, E. J., Krech, A., Kristoffersen, A. B., Laval, V., Leimanis, S., Løvoll, M., Morisset, D., Nemeth, A., Papazova, N., Prins, T. W., Remacle, J., Richl, P., Ruttink, T., Taverniers, I., Tengs, T., van Dijk, J. P., Wulff, D., Žel, J., Zhang, H. and 
Žnidaršič, M. (2013). Towards detection of unknown GMOs. In: Genetically Modified and Non-Genetically Modified Food Supply Chains: Co-Existence and Traceability Bertheau, Y. (Ed), pp. 367-382. https://onlinelibrary.wiley.com/doi/abs/10.1002/97 81118373781.ch20.

Holst-Jensen, A., Bertheau, Y., Alnutt, T., Broll, H., De Loose, M., Grohmann, L., Henry, C., Hougs, L., Moens, W., Morisset, D., Prins, T.W., Suter, D. and Zhang, D. (2011). Overview on the detection, interpretation and reporting on the presence of unauthorised genetically modified materials. Guidance document from the European Network of GMO Laboratories (ENGL). ENGL ad hoc working group on "unauthorised GMOs". In Scientific and Technical Research series (European Commission, Joint research Centre. IHCP), p. 58.

Holst-Jensen, A., Bertheau, Y., de Loose, M., Grohmann, L., Hamels, S., Hougs, L., Morisset, D., Pecoraro, S., Pla, M., den Bulcke, M. V. and Wulff, D. (2012). Detecting un-authorized genetically modified organisms (GMOs) and derived materials. Biotechnology Advances 30(6), 1318-1335.

Holst-Jensen, A., De Loose, M. and Van den Eede, G. (2006). Coherence between legal requirements and approaches for detection of genetically modified organisms (GMOs) and their derived products. Journal of Agricultural and Food Chemistry 54(8), 2799-2809.

Hougs, L., Gatto, F., Goerlich, O., Grohmann, L., Lieske, K., Mazzara, M., Narendja, F., Ovesná, J., Papazova, N., Scholtens, I. and Žel, J. (2017). Verification of analytical methods for GMO testing when implementing interlaboratory validated methods (version 2). In JRC Technical Report, Joint Research Centre (Ed). (Ispra, Italy: Joint Research Centre), p. 35.

Husby, J. (2007). Definitions of GMO/LMO and modern biotechnology. In Biosafety First: Holistic Approaches to Risk and Uncertainty in Genetic Engineering and Genetically Modified Organisms Traavick T. and Lim L. C. (Eds). (Trondheim, NO: Tapir Academic Publishers), pp. 8.

Ikbal, J., Lim, G. S. and Gao, Z. (2015). The hybridization chain reaction in the development of ultrasensitive nucleic acid assays. TrAC Trends in Analytical Chemistry 64, 86-99.

Ikeuchi, M., Favero, D. S., Sakamoto, Y., Iwase, A., Coleman, D., Rymen, B. and Sugimoto, K. (2019). Molecular mechanisms of plant regeneration. Annual Review of Plant Biology 70, 377-406.

International Organization for Standardization (ISO) (2004). Foodstuffs-methods for the detection of genetically modified organisms and derived products-protein based methods. CEN ISO 21572:2004 (International Organization for Standardization), p. 21.

International Organization for Standardization (ISO) (2005a). Foodstuffs-methods of analysis for the detection of genetically modified organisms and derived products-quantitative nucleic acids based methods. ISO 21570:2005. (International Organization for Standardization), p. 103.

International Organization for Standardization (ISO) (2005b). Foodstuffs-methods of analysis for the detection of genetically modified organisms and derived productsqualitative nucleic acids based methods. CEN / ISO 21571:2005 (International Organization for Standardization), p. 69.

International Organization for Standardization (ISO) (2005c). Foodstuffs-methods of analysis for the detection of genetically modified organisms and derived productsqualitative nucleic acid based methods. ISO 21569:2005 (International Organization for Standardization), p. 103. 
International Organization for Standardization (ISO) (2005d). Foodstuffs-nucleic acid based methods of analysis of genetically modified organisms and derived productsinformation to be supplied and procedure for the addition of methods to ISO 21569, ISO 21570 or ISO 21571. ISO /TS 21098:2005 (International Organization for Standardization), p. 18.

International Organization for Standardization (ISO) (2006). Foodstuffs-methods of analysis for the detection of genetically modified organisms and derived productsgeneral requirements and definitions. ISO 24276:2006, (International Organization for Standardization), p. 17.

International Organization for Standardization (ISO) (2007). Traceability in the feed and food chain-general principles and basic requirements for system design and implementation. ISO 22005:2007. (International Organization for Standardization), p. 14.

International Organization for Standardization (ISO) (2015a). Quality management systems-fundamentals and vocabulary. ISO 9000:2015 (International Organization for Standardization), p. 51.

International Organization for Standardization (ISO) (2015b). Quality management systemsrequirements. ISO 9001:2015 (International Organization for Standardization), pp. 29.

International Organization for Standardization (ISO/TC 34/SC 16) (2015). Molecular biomarker analysis-S.S.R. analysis of maize (ISO/TR 17623:2015) (International Organization for Standardization), p. 6.

International Organization for Standardization (ISO) (2017). General requirements for the competence of testing and calibration laboratories. ISO/IEC 17025:2017, (International Organization for Standardization), p. 31.

International Organization for Standardization (ISO) (2019a). Foodstuffs-principles of selection and criteria of validation for varietal identification methods using specific nucleic acid (ISO 13495:2013), (International Organization for Standardization), p. 13.

International Organization for Standardization (ISO) (2019b). Molecular biomarker analysis-determination of the performance characteristics of qualitative measurement methods and validation of methods (ISO/TS 16393), (International Organization for Standardization), p. 28.

International Organization for Standardization (ISO) (2019c). Molecular biomarker analysis-methods of analysis for the detection and identification of animal species in foods and food products (nucleic acid-based methods)-general requirements and definitions. ISO 20813:2019, (International Organization for Standardization), p. 27.

International Organization for Standardization (ISO) (2020). Molecular biomarker analysis-method for the statistical evaluation of analytical results obtained in testing sub-sampled groups of genetically modified seeds and grains-general requirements and definitions. ISO/DIS 22753. Technical Committee: ISO/TC 34/SC 16 Horizontal methods for molecular biomarker analysis (International Organization for Standardization), p. 25.

Irshad, A., Guo, H., Zhang, S. and Liu, L. (2020). TILLING in cereal crops for allele expansion and mutation detection by using modern sequencing technologies. Agronomy 10(3), 405.

Jablonka, E. and Lamb, M. J. (2002). The changing concept of epigenetics. Annals of the New York Academy of Sciences 981(1), 82-96. 
Kantar (2019). Special Eurobarometer-wave EB91.3. Food safety in the EU Survey requested by the European Food Safety Authority (EFSA) and co-ordinated by the European Commission, Directorate-General for Communication. In: Special Eurobarometer EFSA (Ed). (European Food Safety Authority, Parma, Italy), p. 104. https://www.efsa.europa.eu/sites/default/files/corporate_publications/files/ Eurobarometer2019_Food-safety-in-the-EU_Full-report.pdf.

Karp, A. (1994). Origins, causes and uses of variation in plant tissue cultures. In: Plant Cell and Tissue Culture Vasil, I. K. and Thorpe, T. A. (Eds). (Dordrecht: Springer Netherlands), p. 139-151.

Kay, S. and Paoletti, C. (2001). Sampling Strategies for GMO Detection And/Or Quantification, I JRC (Ed). (Ispra, Italy: Joint Research Center), p. 16.

Kobilinsky, A. and Bertheau, Y. (2005). Minimum cost acceptance sampling plans for grain control, with application to GMO detection. Chemometrics and Intelligent Laboratory Systems 75(2), 189-200.

Korir, N. K., Han, J., Shangguan, L., Wang, C., Kayesh, E., Zhang, Y. and Fang, J. (2013). Plant variety and cultivar identification: advances and prospects. Critical Reviews in Biotechnology 33(2), 111-125.

Krishna, G., Nath, J. and Ong, T. (1987). Mitomycin C-induced sister chromatid exchanges in vivo and in vivo/in vitro in mice and Chinese hamsters. Environmental and Molecular Mutagenesis 10(2), 157-167.

Kumar, S., Kumar, A. and Venkatesan, G. (2018). Isothermal nucleic acid amplification system: an update on methods and applications. Journal of Genetics and Genomes 2,1-5.

Kurowska, M., Daszkowska-Golec, A., Gruszka, D., Marzec, M., Szurman, M., Szarejko, I. and Maluszynski, M. (2011). Tilling-a shortcut in functional genomics. Journal of Applied Genetics 52(4), 371-390.

Kwon, Y. S., Lee, J. M., Yi, G. B., Yi, S. I., Kim, K. M., Soh, E. H., Bae, K. M., Park, E. K., Song, I. H. and Kim, B. D. (2005). Use of S. S. R. Markers to complement tests of Distinctiveness, Uniformity, and Stability (DUS) of Pepper (Capsicum annuum L.) varieties. Molecules and Cells 19(3), 428-435.

Laffont, J. L., Remund, K. M., Wright, D., Simpson, R. D. and Gregoire, S. (2005). Testing for adventitious presence of transgenic material in conventional seed or grain lots using quantitative laboratory methods: statistical procedures and their implementation. Seed Science Research 15(3), 197-204.

Ledford, H. (2016). Plant-genome hackers seek better ways to produce customized crops. Nature 539, 16-17.

Levidow, L. and Marris, C. (2001). Science and governance in Europe: lessons from the case of agricultural biotechnology. Science and Public Policy 28(5), 345-360.

Li, C.-X., Xu, W.-G., Guo, R., Zhang, J.-Z., Qi, X.-L., Hu, L. and Zhao, M.-Z. (2018). Molecular marker assisted breeding and genome composition analysis of Zhengmai 7698, an elite winter wheat cultivar. Scientific Reports 8, 322.

Liu, M., Clarke, L. J., Baker, S. C., Jordan, G. J. and Burridge, C. P. (2020). A practical guide to DNA metabarcoding for entomological ecologists. Ecological Entomology 45(3), 373-385.

Liu, X. S. (2007). Getting started in tiling microarray analysis. PLOS Computational Biology $3(10), 1842-1844$.

Lobato, I. M. and O'Sullivan, C. K. (2018). Recombinase polymerase amplification: basics, applications and recent advances. Trends in Analytical Chemistry : TRAC 98, 19-35. 
Macarthur, R. and von Holst, C. (2012). A protocol for the validation of qualitative methods of detection. Analytical Methods 4(9), 2744-2754.

Mason, M. G. and Botella, J. R. (2019). A simple, robust and equipment-free DNA amplification readout in less than 30 seconds. RSC Advances 9(42), 24440-24450.

Matsaunyane, L. B. T. and Dubery, I. A. (2018). Molecular Approaches to Address Intended and unintended effects and substantial equivalence of Genetically Modified Crops. In: Transgenic Crops-Emerging Trends and Future Perspectives Khan, M. S. and Malik, K. A. (Eds). (IntechOpen), pp. 115-131. https://api.intechopen.com/chapter/ pdf-download/62946.pdf.

McCallum, C. M., Comai, L., Greene, E. A. and Henikoff, S. (2000a). Targeted screening for induced mutations. Nature Biotechnology 18(4), 455-457.

McCallum, C. M., Comai, L., Greene, E. A. and Henikoff, S. (2000b). Targeting induced local lesions in genomes (TILLING) for plant functional genomics. Plant Physiology 123(2), 439-442.

Maher, M. F., Nasti, R. A., Vollbrecht, M., Starker, C. G., Clark, M. D. and Voytas, D. F. (2020). Plant gene editing through de novo induction of meristems. Nature Biotechnology 38(1), 84-89.

Manzanares, C., Yates, S., Ruckle, M., Nay, M. and Studer, B. (2016). TILLING in forage grasses for gene discovery and breeding improvement. New Biotechnology 33(5 Part B), 594-603.

Martínez, O. (2018). Selection of molecular markers for the estimation of somaclonal variation. In: Plant Cell Culture Protocols Loyola-Vargas, V. M. and Ochoa-Alejo, N. (Eds). (New York, NY: Springer), pp. 103-129.

Messéan, A., Angevin, F., Gomez-Barbero, M., Menrad, K. and Rodriguez-Cerezo, E. (2006). New case studies on the coexistence of GM and non-GM crops in European agriculture. EUR22102 EN, Joint Research Centre (Ed). (Seville, Spain: JRC-IPTS), pp. 116.

Miao, P., Tang, Y., Wang, B., Yin, J. and Ning, L. (2015). Signal amplification by enzymatic tools for nucleic acids. TrAC Trends in Analytical Chemistry 67, 1-15.

Michelini, E., Simoni, P., Cervenini, L., Mezzanotte, L. and Roda, A. (2008). New trends in bioanalytical tools for the detection of genetically modified organisms: an update. Analytical and Bioanalytical Chemistry 392(3), 355-367.

Minkkinen, P., Esbensen, K. H. and Paoletti, C. (2012). Representative sampling of large kernel lots II. Application to soybean sampling for GMO control. TrAC Trends in Analytical Chemistry 32, 165-177.

Minogue, T. D., Koehler, J. W., Stefan, C. P. and Conrad, T. A. (2019). Next-Generation Sequencing for biodefense: biothreat detection, forensics, and the clinic. Clinical Chemistry 65(3), 383-392.

Miraglia, M., Onori, R., Berben, G., Janssen, E., Oger, R., Planchon, V., Macarthur, R., Teresa Esteve, M. J., Melé, E., Nadal, A., Pla, M. Ancel, V., Kobilinsky, A., Brera, C., De Giacomo, M., De Vivo, M., Di Domenicantonio, C., Palmaccio, E., Prantera, E., Bellocchi, G., Blejec, A., Čergan, Z., Kozjak, P., Meglič, V., Rostohar, K., Šuštar-Vozlič J., Vrščaj, B., Malcevsky, A. and Marmiroli, N. (2009). Report on Fit-for-Purpose, Cost-Effective Sampling Strategies, D4.9 deliverable, Co-Extra (Ed). (Paris, France: Co-Extra Research programme), p. 87.

Mojtahedi, M., Skupin, A., Zhou, J., Castaño, I. G., Leong-Quong, R. Y. Y., Chang, H., Trachana, K., Giuliani, A. and Huang, S. (2016). Cell fate decision as high-dimensional critical state transition. PLoS Biology 14(12), e2000640. 
Monticolo, F., Palomba, E., Termolino, P., Chiaiese, P., de Alteriis, E., Mazzoleni, S. and Chiusano, M. L. (2020). The role of DNA in the extracellular environment: a focus on NETs, RETs and biofilms. Frontiers in Plant Science 11, 589837.

Moreno, A., Carrington, J. T., Albergante, L., Al Mamun, M., Haagensen, E. J., Komseli, E. S., Gorgoulis, V. G., Newman, T. J. and Blow, J. J. (2016). Unreplicated DNA remaining from unperturbed $\mathrm{S}$ phases passes through mitosis for resolution in daughter cells. Proceedings of the National Academy of Sciences of the United States of America 113(39), E5757-E5764.

Morrow, J. (1975). On the relationship between spontaneous mutation rates in vivo and in vitro. Mutation Research 33(2-3), 367-372.

Mozgová, I., Köhler, C., Gaudin, V. and Hennig, L. (2015). The many faces of plant chromatin: meeting summary of the $4^{\text {th }}$ European workshop on plant chromatin 2015, Uppsala, Sweden. Epigenetics 10(11), 1084-1090.

National Academies of Sciences Engineering and Medicine (2004). Safety of Genetically Engineered Foods Approaches to Assessing Unintended Health Effects, Institute of Medicine and National research Council of the National Academies, ed. (Washington DC: Institute of Medicine and National research Council of the National Academies), p. 254.

National Research Council (2009). Science and Decisions - Advancing Risk Assessment. (National Academy of Sciences), p. 424. http://www.nap.edu/download.php?record -id=12209.

Onori, R., Šuštar-Vozlič, J., Bellocchi, G., Berben, G., Blejec, A., Brera, C., Čergan, Z., Debeljak, M., De Giacomo, M., De Vivo, M., Esteve, T., Janssen, E., Kozjak, P., Leprince, F., Macarthur, R., Malcevchi, A., Marmiroli, N., Meglič, V., Melé, E., Messeguer, J., Miraglia, M., Nadal, A., Oger, R., Palmaccio, E., Pla, M., Planchon, V., Prantera, E., Rostohar, K. and Vrščaj, B. (2013). GMO sampling strategies in food and feed chains. In: Genetically Modified and Non-Genetically Modified Food Supply Chains: Co-Existence and Traceability Bertheau, Y. (Ed). (Wiley-Blackwell), p. 245-272.

Orr, A. J., Padovan, A., Kainer, D., Külheim, C., Bromham, L., Bustos-Segura, C., Foley, W., Haff, T., Hsieh, J. F., Morales-Suarez, A., Cartwright, R. A. and Lanfear, R. (2020). A phylogenomic approach reveals a low somatic mutation rate in a long-lived plant. Proceedings. Biological Sciences 287(1922), 20192364.

Ouyang, W. and Han, J. (2019). Universal amplification-free molecular diagnostics by billion-fold hierarchical nanofluidic concentration. Proceedings of the National Academy of Sciences of the United States of America 116(33), 16240-16249.

Paoletti, C., Donatelli, M., Kay, S. and Van den Eede, G. (2003). Simulating kernel lot sampling: the effect of heterogeneity on the detection of GMO contaminations. Seed Science and Technology 31(3), 629-638.

Parida, M. M., Dash, P. K. and Shukla, J. (2020). Advance detection technologies for select biothreat agents. In Handbook on Biological Warfare Preparedness, pp. 83-102. https://www.ncbi.nlm.nih.gov/pmc/articles/PMC7153318/.

Parida, M., Sannarangaiah, S., Dash, P. K., Rao, P. V. L. and Morita, K. (2008). Loop mediated isothermal amplification (LAMP): a new generation of innovative gene amplification technique; perspectives in clinical diagnosis of infectious diseases. Reviews in Medical Virology 18(6), 407-421.

Parisi, S., Barone, C. and Sharma, R. K. (2016). RASFF alert and information notifications. A statistical review. In Chemistry and Food Safety in the EU: The Rapid Alert System for 
Food and Feed (RASFF) (Cham: Springer International Publishing), pp. 19-46. https:// link.springer.com/book/10.1007/978-3-319-33393-9.

Pasquali, F., Do Valle, I., Palma, F., Remondini, D., Manfreda, G., Castellani, G., Hendriksen, R. S. and De Cesare, A. (2019). Application of different DNA extraction procedures, library preparation protocols and sequencing platforms: impact on sequencing results. Heliyon 5, e02745.

Peters, B. A., Kermani, B. G., Alferov, O., Agarwal, M. R., McElwain, M. A., Gulbahce, N., Hayden, D. M., Tang, Y. T., Zhang, R. Y., Tearle, R., Crain, B., Prates, R., Berkeley, A., Munné, S. and Drmanac, R. (2015). Detection and phasing of single base de novo mutations in biopsies from human in vitro fertilized embryos by advanced wholegenome sequencing. Genome Research 25(3), 426-434.

Piskata, Z., Servusova, E., Babak, V., Nesvadbova, M, and Borilova, G. (2019). The quality of DNA isolated from processed food and feed via different extraction procedures. Molecules (Basel, Switzerland) 24, 1188.

Pitard, F. (2019). Theory of Sampling and Sampling Practice, $3^{\text {rd }}$ edn, Chapman and Hall/ CRC, New York (CRC Press), p. 726.

Pratap, A., Prajapati, U., Singh, C. M., Gupta, S., Rathore, M., Malviya, N., Tomar, R., Gupta, A. K., Tripathi, S. and Singh, N. P. (2018). Potential, constraints and applications of in vitro methods in improving grain legumes. Plant Breeding 137(3), 235-249.

Price, B. and Cotter, J. (2014). The GM contamination register: a review of recorded contamination incidents associated with genetically modified organisms (GMOs), 1997-2013. International Journal of Food Contamination 1(1), 5.

Quan, P. L., Sauzade, M. and Brouzes, E. (2018). dPCR: a technology review. Sensors 18(4), 1271.

Que, Q., Elumalai, S., Li, X., Zhong, H., Nalapalli, S., Schweiner, M., Fei, X., Nuccio, M., Kelliher, T., Gu, W., Chen, Z. and Chilton, M. D. (2014). Maize transformation technology development for commercial event generation. Frontiers in Plant Science 5, 379.

Regulatory Committee of Directive 2001/18 (2020). Seed Testing Convergence, p. 6. https://ec.europa.eu/food/sites/food/files/plant/docs/reg-com_2001-18-ec_ 20200604_result_seed-testing-convergence.pdf.

Remund, K. M., Dixon, D. A., Wright, D. L. and Holden, L. R. (2001). Statistical considerations in seed purity testing for transgenic traits. Seed Science Research $11,101-119$.

Ribarits, A., Eckerstorfer, M., Simon, S. and Stepanek, W. (2021). Genome-edited plants: opportunities and challenges for an anticipatory detection and identification framework. Foods 10, 430.

Richard, A., Boullu, L., Herbach, U., Bonnafoux, A., Morin, V., Vallin, E., Guillemin, A., Papili Gao, N., Gunawan, R., Cosette, J., Arnaud, O., Kupiec, J. J., Espinasse, T., Gonin-Giraud, S. and Gandrillon, O. (2016). Single-cell-based analysis highlights a surge in cell-to-cell molecular variability preceding irreversible commitment in a differentiation process. PLOS Biology 14(12), e1002585.

Rizov, I. and Rodriguez Cerezo, E. (2014). Best practice documents for coexistence of genetically modified crops with conventional and organic farming. 2. Monitoring efficiency of coexistence measures in maize crop production. EUR $26261 \mathrm{EN}$. In JRC Scientific and Policy Reports, Institute for Prospective and Technological Studies Joint Research Centre, ed. (Spain: Joint Research Centre), p. 36. 
Rizov, I. and Rodriguez-Cerezo, E. (2015). The approach of European coexistence bureau for sustainable coexistence of genetically modified soybean crops with conventional and organic farming. In International Conference on Coexistence between Genetically Modified (GM) and non-GM based Agricultural Supply Chains (GMCC). GMCC-15: Seventh GMCC (Amsterdam, the Netherlands), pp. 20.

Robin, J. D., Ludlow, A. T., LaRanger, R., Wright, W. E. and Shay, J. W. (2016). Comparison of DNA quantification methods for next generation sequencing. Scientific Reports 6, 24067.

Rose, M., Poms, R., Macarthur, R., Popping, B. and Ulberth, F. (2011). What is the best way to ensure that valid analytical methods are used for food control? Quality Assurance and Safety of Crops and Foods 3(3), 123-134.

Rostoks, N. (2021). Implications of the EFSA scientific opinion on Site Directed Nucleases 1 and 2 for risk assessment of genome-edited plants in the EU. Agronomy 11(3), 572.

Rousseau, D. -D., Schevin, P., Duzer, D., Cambon, G., Ferrier, J., Jolly, D. and Poulsen, U. (2006). New evidence of long distance pollen transport to southern Greenland in late spring. Review of Palaeobotany and Palynology 141(3-4), 277-286.

Ruiz, M., Oustric, J., Santini, J. and Morillon, R. (2020). Synthetic polyploidy in grafted crops. Frontiers in Plant Science 11, 540894.

Ruppert, K. M., Kline, R. J. and Rahman, M. S. (2019). Past, present, and future perspectives of environmental DNA (eDNA) metabarcoding: a systematic review in methods, monitoring, and applications of global eDNA. Global Ecology and Conservation 17, e00547.

Ruttink, T., Demeyer, R., Van Gulck, E., Van Droogenbroeck, B., Querci, M., Taverniers, I. and De Loose, M. (2010). Molecular toolbox for the identification of unknown genetically modified organisms. Analytical and Bioanalytical Chemistry 396(6), 2073-2089.

Sablowski, R. (2016). Coordination of plant cell growth and division: collective control or mutual agreement? Current Opinion in Plant Biology 34, 54-60.

Sajali, N., Wong, S. C., Hanapi, U. K., Abu Bakar @ Jamaluddin, S., Tasrip, N. A. and Mohd Desa, M. N. (2018). The challenges of DNA extraction in different assorted food matrices: a review. Journal of Food Science 83, 2409-2414.

Schaart, J. G. and Visser, R. G. F. (2009). Novel Plant Breeding Techniques. Consequences of new genetic modification-based plant breeding techniques in comparison to conventional plant breeding (COGEM), p. 60.

Schmitz, T. G., Schmitz, A. and Moss, C. B. (2005). The economic impact of StarLink corn. Agribusiness 21(3), 391-407.

Scientific advice mechanism (SAM) (2017). New techniques in agricultural biotechnology. In Explanatory Note, High Level Group of Scientific Advisors, ed. (European Commission), p. 152.

SeedQuest (2011). New database of detection methods is the definitive global resourceonline resource provides public access to the most comprehensive and accurate biotechnology trait testing methods available. In SeedQuest (Brussels, Belgium: SeedQuest).

Singh, M., Pal, D., Sood, P. and Randhawa, G. (2019a). Loop-mediated isothermal amplification assays: rapid and efficient diagnostics for genetically modified crops. Food Control 106, 106759.

Singh, R., lquebal, M. A., Mishra, C. N., Jaiswal, S., Kumar, D., Raghav, N., Paul, S., Sheoran, S., Sharma, P., Gupta, A., Tiwari, V., Angadi, U. B., Kumar, N., Rai, A., Singh, G. P., 
Kumar, D. and Tiwari, R. (2019b). Development of model web-server for crop variety identification using throughput SNP genotyping data. Scientific Reports 9(1), 5122.

Skirvin, R. M., McPheeters, K. D. and Norton, M. (1994). Sources and frequency of somaclonal variation. Hortscience 29(11), 1232-1237.

Snow, A. A. (2012). Illegal gene flow from transgenic creeping bentgrass: the saga continues. Molecular Ecology 21(19), 4663-4664.

Sohn, H. B., Kim, S. J., Hwang, T. Y., Park, H. M., Lee, Y. Y., Markkandan, K., Lee, D., Lee, S., Hong, S. Y., Song, Y. H., Koo, B. C. and Kim, Y. H. (2017). Barcode system for genetic identification of soybean [Glycine max (L.) Merrill] cultivars using InDel markers specific to dense variation blocks. Frontiers in Plant Science 8, 520.

Song, S., Ghosh, J., Mainigi, M., Turan, N., Weinerman, R., Truongcao, M., Coutifaris, C. and Sapienza, C. (2015). DNA methylation differences between in vitro- and in vivo-conceived children are associated with A.R.T. procedures rather than infertility. Clinical Epigenetics 7, 41.

Spranger (2015). Legal Analysis of the applicability of Directive 2001/18/EC on genome editing technologies. Commissioned by the German Federal Agency for Nature Conservation (Faculty of Law, Rheinische Friedrich-Wilhelms-University Bonn), pp. 51.

Stave, J. W. (2002). Protein immunoassay methods for detection of biotech crops: applications, limitations, and practical considerations. Journal of $A O A C$ International 85(3), 780-786.

Strain, K. E., Whiting, S. A. and Lydy, M. J. (2014). Laboratory and field validation of a Cry1 Ab protein quantitation method for water. Talanta 128, 109-116.

Sugumar, D. and Kong, L. (2008). Lab-on-Chip devices for biodefense applications. In: Encyclopedia of Microfluidics and Nanofluidics Li, D. (Ed). (Boston, MA: Springer), p. 907-910.

Sustar-Vozlic, J., Rostohar, K., Blejec, A., Kozjak, P., Cergan, Z. and Meglic, V. (2010). Development of sampling approaches for the determination of the presence of genetically modified organisms at the field level. Analytical and Bioanalytical Chemistry 396(6), 2031-2041.

Thorpe, T. (2012). History of plant tissue culture. In: Plant Cell Culture Protocols LoyolaVargas, V. M. and Ochoa-Alejo, N. (Eds). (Totowa, NJ: Humana Press), p. 9-27.

Trapmann, S., Charles-Delobel, C., Corbisier, P., Emons, H., Hougs, L., Philipp, P., Sandberg, M. and Schulze, M. (2014). European Technical Guidance Document for the Flexible Scope Accreditation of Laboratories Quantifying GMOs. (Ispra, Italy: Joint Research Center), p. 50.

Trapmann, S., Corbisier, P., Schimmel, H. and Emons, H. (2010). Towards future reference systems for GM analysis. Analytical and Bioanalytical Chemistry 396(6), 1969-1975.

Unterseer, S., Bauer, E., Haberer, G., Seidel, M., Knaak, C., Ouzunova, M., Meitinger, T., Strom, T. M., Fries, R., Pausch, H., Bertani, C., Davassi, A., Mayer, K. F. and Schön, C. C. (2014). A powerful tool for genome analysis in maize: development and evaluation of the high density $600 \mathrm{k}$ SNP genotyping array. BMC Genomics 15, 823.

UPOV (2011). Guidelines for DNA-Profiling: Molecular Markers and Database Construction ("BMT Guidelines"), UPOV, ed. (Geneva, Switzerland: International Union for the Protection of New Varieties of Plants (UPOV)), p. 16.

UPOV (2019a). Advances in the Construction and Application of DNA Fingerprinting Database in Maize, UPOV, ed. (Geneva, Switzerland: International Union for the Protection of New Varieties of Plants (UPOV)), p. 12. 
UPOV (2019b). DNA-Based Methods for Variety Testing: ISTA Approach, UPOV, ed. (Geneva, Switzerland: International Union for the Protection of New Varieties of Plants (UPOV)), p. 9.

UPOV (2019c). Guidance for New Types and Species, UPOV, ed. (Geneva, Switzerland: International Union for the Protection of New Varieties of Plants (UPOV)), p. 13.

UPOV (2019d). Guidance on the Use of Biochemical and Molecular Markers in the Examination of Distinctness, Uniformity and Stability (DUS), UPOV, ed. (Geneva, Switzerland: International Union for the Protection of New Varieties of Plants (UPOV)), p. 12.

Vain, P. (2007). Trends in G.M. crop, food and feed safety literature. Nature Biotechnology 25(6), 624-626.

Van den Bulcke, M., De Schrijver, A., De Bernardi, D., Devos, Y., MbongoMbella, G., Casi, A. L., Moens, W. and Sneyers, M. (2007). Detection of genetically modified plant products by protein strip testing: an evaluation of real-life samples. European Food Research and Technology 225(1), 49-57.

van den Bulk, R. W., Löffler, H. J. M., Lindhout, W. H. and Koornneef, M. (1990). Somaclonal variation in tomato: effect of explant source and a comparison with chemical mutagenesis. TAG. Theoretical and Applied Genetics. Theoretische und Angewandte Genetik 80(6), 817-825.

Van Der Meer, P., Angenon, G., Bergmans, H., Buhk, H. J., Callebaut, S., Chamon, M., Eriksson, D., Gheysen, G., Harwood, W., Hundleby, P., et al. (2021). The status under EU law of organisms developed through novel genomic techniques. European Journal of Risk Regulation 48, 1-20.

Van Eenennaam, A. L., Wells, K. D. and Murray, J. D. (2019). Proposed US regulation of gene-edited food animals is not fit for purpose. npj Science of Food 3, 3.

von Gotz, F. (2010). See what you eat-broad GMO screening with microarrays. Analytical and Bioanalytical Chemistry 396(6), 1961-1967.

Vora, G. J., Meador, C. E., Anderson, G. P. and Taitt, C. R. (2008). Comparison of detection and signal amplification methods for DNA microarrays. Molecular and Cellular Probes 22(5-6), 294-300.

Waiblinger, H. U., Ernst, B., Graf, N. and Pietsch, K. (2007). Ring trial validation of a method for the extraction of DNA from soy lecithins. Journal für Verbraucherschutz und Lebensmittelsicherheit 2, 113-115.

Walker, F. M. and Hsieh, K. (2019). Advances in directly amplifying nucleic acids from complex samples. Biosensors 9, 117.

Watson, A., Ghosh, S., Williams, M. J., Cuddy, W. S., Simmonds, J., Rey, M.-D. and Asyraf Md Hatta, M., Hinchliffe, A., Steed, A., Reynolds, D., Adamski, N. M., Breakspear, A., Korolev, A., Rayner, T., Dixon, L. E., Riaz, A., Martin, W., Ryan, M., Edwards, David, Batley, J., Raman, H., Carter, J., Rogers, C., Domoney, C., Moore, G., Harwood, W., Nicholson, P., Dieters, M. J., DeLacy, I. H., Zhou, J., Uauy, C., Boden, S. A., Park, R. F., Wulff, B. B. H. and Hickey, L. T. (2018). Speed breeding is a powerful tool to accelerate crop research and breeding. Nature Plants 4, 23-29.

Wiener, J. B. and Rogers, M. D. (2002). Comparing precaution in the United States and Europe. Journal of Risk Research 5(4), 317-349.

Wilkesa, T., Nixona, G. and Burns, M. (2016). Recent developments in DNA-based screening approaches for detection of GMOs. Journal of the Association of Public Analysts 44, 40-50. 
Žárský, V., Cvrčková, F., Potocký, M. and Hála, M. (2009) Exocytosis and cell polarity in plants-exocyst and recycling domains. New Phytologist 183(2), 255-272.

Žel, J., Cankar, K., Ravnikar, M., Camloh, M. and Gruden, K. (2006). Accreditation of GMO detection laboratories: improving the reliability of GMO detection. Accreditation and Quality Assurance 10(10), 531-536.

Žel, J., Milavec, M., Morisset, D., Plan, D., Eede, G. v. d. and Gruden, K. (2012). How to Reliably Test for GMO's (Springer), p. 95.

Zhao, L.-Y., Song, J., Liu, Y., Song, C.-X. and Yi, C. (2020). Mapping the epigenetic modifications of DNA and RNA. Protein \& Cell 11, 792-808.

Żmieńko, A., Guzowska-Nowowiejska, M., Urbaniak, R., Pląder, W., Formanowicz, P. and Figlerowicz, M. (2011). A tiling microarray for global analysis of chloroplast genome expression in cucumber and other plants. Plant Methods 7, 29.

Zou, Y., Mason, M. G. and Botella, J. R. (2020). Evaluation and improvement of isothermal amplification methods for point-of-need plant disease diagnostics. PLoS ONE 15(6), e0235216. 
